\title{
Nobleza y fiscalidad en la Ruta de las Indias: el emporio señorial de Sanlúcar de Barrameda (1576-1641)
}

\author{
Luis Salas Almela \\ Instituto Universitario de Florencia
}

En este artículo se estudia la influencia que un emporio señorial de la magnitud de Sanlúcar de Barrameda - sede de la Casa de Medina Sidonia - tuvo en la configuración y desarrollo de las instituciones comerciales de la Carrera de Indias. En conjunto proponemos un replanteamiento de aquel entramado de intereses a la luz de las dificultades con las que topó la aplicación sobre el terreno - la Baja Andalucía, caracterizada por la gran discontinuidad jurisdiccional- de las medidas fiscales diseñadas en la Corte. El lapso cronológico abarca desde las primeras visitas generales al sistema aduanero del Atlántico sur — hacia 1580 - a la caída en desgracia del IX duque en 1641, tras su implicación en la famosa conjura.

PAlabras ClaVE: nobleza, poder, Medina Sidonia, política fiscal, comercio, instituciones.

This article studies the influence that a relevant seigneurial emporia, as it was Sanlúcar de Barrameda - residence of the Dukes of Medina Sidonia-, had in the implementation and development of the commercial institutions of the Carrera de Indias. In general terms, we suggest a review of this complex taking into account the difficult praxis of the royal politics in an area as much discontinuous - from the point of view of the jurisdictionas it was the Lower Andalusia. The period chosen goes from the first royal attempts to inquiry in the South Atlantic commerce, to the fall of the IX duke in 1641 accused of conspiracy.

KEYwORDS: nobility, power, Medina Sidonia, fiscal policy, commerce, institutions.

Según Braudel, "el atlántico de los españoles es una elipse de la que Sevilla, las Canarias, las Antillas y las Azores marcan el trazado, siendo a la vez puertos de arribada y sus fuerzas motrices". Tras más de medio siglo

1 Braudel, F.: El Mediterráneo y el mundo mediterráneo en tiempos de Felipe II, 2 tomos, Madrid, Fondo de Cultura Económica, 1993 [1949], vol. I, pág. 295; también P. Chaunu ha señalado las condiciones geográficas privilegiadas para cubrir la travesía del Atlántico de las que disfruta la franja costera entre Lisboa y Salé. En Conquista y explotación de los nuevos mundos, Labor, Barcelona, 1984, págs. 135-137. 
del comienzo de la explotación sistemática de las posibilidades expansivas del imperio americano por parte de la Corona de Castilla, una de las principales características de la Baja Andalucía hacia la década de 1580 era el carácter mercantil de su economía. Esa enorme extensión marítima del "atlántico de los españoles" tenía por cabeza visible a Sevilla. En palabras de Antonio Domínguez Ortiz, "en la base de la fortuna de Sevilla está su elección como puerto privilegiado". ${ }^{2}$ En efecto, el comercio americano potenció las posibilidades de enriquecimiento, no sólo de aquella ciudad, sino de toda una región a la que denominamos Baja Andalucía. ${ }^{3}$

Por otra parte, la Baja Andalucía era, en la Edad Moderna, un área marcadamente señorializada, en la que el realengo constituía casi una excepción geográfica. Buena parte de las más poderosas Casas señoriales castellanas tenían sus sedes en esta región —así los duques de Arcos, Osuna, Alcalá y Medina Sidonia, por sólo citar cuatro de los más destacados ejemplos-. En cambio, las excepciones realengas eran, a su vez, algunas de las más importantes ciudades de la Corona de Castilla: Jerez, Cádiz, Córdoba y la propia Sevilla. ${ }^{4}$ Tal era el peso de estos núcleos de población que la Baja Andalucía era la única zona que cumplía los criterios clásicos de urbanización en toda la Península Ibérica, de entre los cuales destacan, junto con los de población e instituciones, otros referidos a la actividad comercial y a las redes de comunicación en las que se encontraba inserta. ${ }^{5}$

La descripción de Sanlúcar de Barrameda en 1634 por Pedro Texeira dice:

"Es esta ciudad de grande población. Su trato es el mayor que de ningún lugar de toda esta costa. El puerto es capaz de muchos bajeles, aunque no dejan de entrar en él con algún peligro [...]. En esta playa y puerto de Sanlúcar dan fondo los galeones y flotas que vienen de las Indias y aguardan la marea para ir a descargar a Sevilla". ${ }^{6}$

2 Domínguez Ortiz, A.: Orto y ocaso de Sevilla, Servicio de Publicaciones de la Universidad de Sevilla, Sevilla, 1981 [1946], pág. 55.

3 Demarcación que, grosso modo, podemos identificar con las actuales provincias de Huelva, Cádiz, Sevilla y Córdoba.

4 Además, salvo el caso de Cádiz, completamente dependiente del hinterland señorial, se trata de ciudades dotadas de un enorme alfoz. Véase Ponsot, P.: Atlas de Historia Económica de la Baja Andalucía (siglos XVI-XIX), Editoriales Andaluzas, Sevilla, 1986; Windler, Ch.: Elites locales, señores, reformistas. Redes clientelares y monarquía hacia finales del Antiguo Régimen, Universidad de Córdoba, 1997, págs. 47-51.

5 Vries, J. de: La urbanización de Europa, 1500-1800, Crítica, Barcelona, 1987.

6 Pereda, F. y Marías, F. (eds): El atlas del rey Planeta. La "Descripción de España y de las costas y puertos de sus reinos”, de Pedro Texeira (1634), Nerea, Hondarribia, 2002, pág. 344. 
El peligro que representaba la barra de Sanlúcar, que era tan reconocido como para que los reyes castellanos legislasen sobre el volumen máximo de los barcos que hacían la ruta a Indias, ${ }^{7}$ no había impedido el florecimiento comercial en la Baja Edad Media de la propia Sanlúcar ni de Sevilla. Como se ha podido argumentar, hacia 1492 ambas ciudades eran florecientes escalas en la gran ruta comercial marítima que unía la Europa nórdica con la cuenca mediterránea. ${ }^{8}$ Con respecto a la población de Sanlúcar, sabemos que hacia 1640 rondaba los 3.000 vecinos, a los que hay que añadir un alto número de individuos estantes, muchos de ellos en tránsito hacia las Indias. ${ }^{9}$ Esto último se debía a que en Sanlúcar se reunían los diversos cuerpos de los convoyes de la Carrera de Indias para zarpar en conserva. Del mismo modo, en condiciones normales, en Sanlúcar "daban fondo" los galeones y flotas en su viaje de regreso a Europa.

Buena parte de los trabajos que han abordado el comercio oceánico en la Edad Moderna aluden a Sanlúcar como ante-puerto de Sevilla. Sin embargo, más allá de esa evidencia greográfica, se ha tendido a olvidar que Sanlúcar era la sede del mayor poder señorial de la Corona de Castilla, cuya capacidad de interferir en la organización de aquel trasiego merece ser estudiada. ${ }^{10}$ Este artículo explora un aspecto esencial de aquella organización, como es el desarrollo de las instituciones fiscales de la Carrera de Indias, resaltando en su justa medida la dimensión política y fiscal de la participación de los Medina Sidonia en dicho proceso. Pretendemos así comenzar a cubrir el notable olvido historiográfico que ha pesado sobre un emporio señorial clave.

Para ello, en primer lugar, vamos a ubicar la aduna de Sanlúcar en el marco de las grandes instituciones con intereses directos en la fiscalidad sobre el comercio indiano. A continuación, nos aproximaremos a los aprovechamientos fiscales de los Medina Sidonia a través de las denuncias de las que fueron objeto los duques y sus ministros hacia 1580, en un momento clave para el comercio atlántico por cuanto el renovado interés fiscal de

7 Legislación que parece ser era ignorada. Aún en 1629 y 1634 se volvió a insistir en el límite de 550 toneladas. AGI, Indiferente, 433, lib. 4, f. 220v, 29 de enero de 1629 y 434, leg. 6, 363v, 31 de octubre de 1634 .

8 Otte, E.: Sevilla y sus mercaderes a fines de la Edad Media, Universidad de Sevilla, Sevilla, 1996; Moreno Ollero, A.: Sanlúcar de Barrameda a fines de la Edad Media, Diputación de Cádiz, Cádiz, 1983.

9 ADMS, 1.026 y 2.420 .

10 Así, Comellas reconoció a vuela pluma, hace ya más de una década, que los Medina Sidonia tuvieron una activa intervención en la organización de las flotas de Indias. Comellas, J. L.: Sevilla, Cádiz y América. El trasiego y el tráfico, Arguval, Málaga, 1992, pág. 116. 
Felipe II en esta fuente de ingresos produjo cambios notables en la estructura fiscal de la Baja Andalucía. De ahí en adelante analizamos la evolución del sistema, utilizando como hilo conductor los permanentes roces institucionales que no cesaron hasta el destierro del IX duque don Gaspar en 1641.

\section{Una aduana señorial en la Puerta de las Indias}

\section{Consideraciones generales}

Dado que todo territorio señorial tiene una dimensión fiscal —que se define por oposición a las otras fiscalidades señoriales, municipales o realengas-, la doble condición de Sanlúcar de Barrameda como cabeza de un estado nobiliario y antepuerto de Sevilla debe ser puesta en relación con el desarrollo de las instituciones del comercio indiano. Para ello debemos comenzar por situar en su contexto institucional a la principal fuente de riqueza de los Medina Sidonia: su aduna sanluqueña.

La mayor parte de nuestro conocimiento sobre la estructura fiscal impuesta sobre el circuito comercial al que aludimos como Carrera de Indias ha girado en torno a la deslumbrante presencia de la plata americana. Además, ciertos azares historiográficos ${ }^{11}$ han propiciado que la mayor parte de la investigación se orientase a la evaluación del dinero político del rey de España o a la estimación de su contrario, es decir, de la elusión de los derechos regios. Haciendo un somero resumen, debemos señalar que frente a las tesis y la cronología de Chaunu, la discusión sobre la validez de las fuentes oficiales de registro de mercancías ha permitido desmontar algunos mitos sobre la llamada "crisis del siglo XVII" que, en el aspecto concreto de este tráfico comercial, daban a entender un desplome en picado del comercio a partir de mediados de la década de $1620 .{ }^{12}$ Como conse-

11 Entre ellos, el carácter innovador de dos estudios de historia económica como lo fueron el de Haring, C. H.: Comercio y navegación entre España y las Indias, Fondo de Cultura Económica, Méjico, 1939 [1918] y el de Hamilton, E. J.: El tesoro americano y la revolución de los precios, 15011650, Ariel, Barcelona, 1975 [1934].

12 Se pueden distinguir dos corrientes: por un lado, aquella que interpreta la caída en los registros de la Casa de la Contratación por un auge del contrabando, representada por M. Morineau en su Histoire economique et sociale du monde, Presses Universitaires de France, París, 1977, [o en su ya clásico Incroyables gazettes et fabuleux metaux, Maison des Sciences del'homme, Cambridge-París, 1985, en especial "Gazettes hollandaises et trésors américains (1580-1660)", 42-119], seguida entre otros por Oliva Melgar, J. M. en "Realidad y ficción en el monopolio de indias", Manuscrits, 14 (1996), 
cuencia de esta revisión, se ha impuesto la idea de que existía todo un circuito comercial que cada vez escapaba más a la inspección de la Corona y que hacia 1690 acabó por absorber la mayor parte del tráfico de todo tipo de mercancías. Así, los iniciales deseos de la Corona de controlar en régimen de monopolio el tráfico comercial con América parece que no pueden ya ser interpretados como el gran leit motiv de la política regia respecto al tráfico mercantil sevillano a lo largo de toda la Edad Moderna. Por el contrario, ahora aceptamos que la lógica regia respecto a los caudales de Indias estaba presidida por un afán recaudatorio conceptualmente menos ambicioso, sobre todo desde que en 1543 se crease el Almojarifazgo Mayor de Indias. ${ }^{13}$ En todo caso, los caudales producidos por aquella fiscalidad suponían "las más importantes rentas que $\mathrm{Su}$ Majestad tiene en toda su Monarquía; pende de ellas toda Castilla, los más principales hombres de ella y la gente más necesitada y todos los monasterios" ${ }^{14}$ Conviene precisar, en todo caso, que en la Baja Andalucía, más que de un comercio, se debería hablar de varios comercios o, con más precisión, de varias ramificaciones de una tupida red comercial en la que esta región era una pieza esencial. Podemos hablar, grosso modo, de cuatro rutas: la Europa mediterránea, la Europa nórdica, el Magreb y América. Respecto a las tres primeras, Sevilla era cabeza de una renta de larga tradición bajo-medieval, el Almojarifazgo Mayor, de cuya caja central dependían todas las aduanas de mar pertenecientes a la Corona castellana entre Ayamonte y Orihuela. ${ }^{15}$

págs. 321-355 y "La metrópoli sin territorio. ¿Crisis del comercio de Indias en el siglo XVII o pérdida del control del monopolio?" en Martínez Shaw, C., y Oliva Melgar, J. M. (eds.): El sistema atlántico español (siglos XVII-XIX), Marcial Pons, Madrid, 2005, págs. 19-73; por otro lado, ciertos autores han insistido más en la validez indicativa de los registros y arqueos para evaluar el desplome del comercio atlántico desde Andalucía, como es el caso de Chaunu, P.: Sevilla y América, Universidad de Sevilla, 1983; y A. García-Baquero, cuya opinión y críticas a Morineau resumió en "Andalucía y los problemas de la carrera de Indias en la crisis del siglo XVII", en II Coloquios de historia de Andalucía. Andalucía Moderna, Tomo I, Universidad de Córdoba, 1980, págs. 533-552; del mismo autor, Andalucía y la Carrera de Indias (1492-1824), Editoriales Andaluzas, Sevilla, 1986. Respecto a la relación de las remesas de plata con la política regia, destacan los trabajos de Álvarez Nogal, C.: El crédito de la Monarquía Hispánica en el reinado de Felipe IV, Junta de Castilla-León, Valladolid, 1997; y Los banqueros de Felipe IV y los metales preciosos americanos (1621-1665), Banco de España, Madrid, 1997.

13 Ulloa, M.: La Hacienda Real de Castilla en el reinado de Felipe II, Fundación Universitaria Española, Madrid, 1977, págs. 284-296.

14 AGS, CJH, 474, carpeta 13. Martín Álvarez de Castro al Consejo, 28 de marzo de 1607.

15 Una descripción de principios del XVII la evalúa en 350 millones de maravedíes y estima en unos 800 los ministros encargados de su cobranza y gestión. Para entonces, el anónimo cronista refiere que casi toda ella estaba consumida en juros y tributos. BN, Mss. 6.043. Ver también Ulloa: $L a$ Hacienda Real..., pág. 284 ss. 
A partir de los años de 1580 se generalizó el arrendamiento del Almojarifazgo Mayor unido con el de Indias, cuya sede también era Sevilla. En consecuencia, cuando, hacia 1600, el beneficio de la renta de los almojarifazgos estaba dedicado casi en su totalidad al pago de deudas consolidadas, la solvencia de los sucesivos arrendadores de ambos caudales había pasado a ser una cuestión política de primer orden. La más cotidiana amenaza contra la viabilidad de esta estructura fiscal era el fraude, cuyo monto en el cambio del siglo era capaz de hacer tambalear toda la estructura de reparto que pesaba sobre esta renta. Por ello, el complejo equilibrio entre las tres presiones principales que pesaban sobre la Corona - los intereses de los grandes comerciantes, el respeto a las jurisdicciones "con mano" en la materia y la defensa de los intereses de los compradores de juros- se debía establecer mediante una negociación en la que la acción judicial era muy delicada, como iremos viendo.

La percepción de los derechos reales y la organización de aquel comercio múltiple fueron el acicate para la creación de un notable complejo institucional radicado en Sevilla que hubo de abrirse camino entre los organismos previamente existentes en la ciudad, que no dejaron de tomar parte en los cambios que se produjeron en la Sevilla del siglo XVI. La Casa de la Contratación, ${ }^{16}$ el Consulado de Sevilla, ${ }^{17}$ la Real Audiencia y el concejo de la ciudad - presidido por el Asistente, alter ego regio equivalente al corregidor $-{ }^{18}$ son las más señeras. Ahora bien, aunque todo esto prueba que Sevilla era en sí misma un gran centro de poder, es imprescindible dar entrada en nuestro esquema a los cauces institucionales que vinculaban a cada uno de estos organismos con el entorno de poder al que aludimos

16 Schäfer, H.: El Consejo real y supremo de las Indias. Historia y organización del Consejo y de la Casa de la Contratación de las Indias, 2 vols., Junta de Castilla-León, Valladolid, 2003 [1935]; Cervera Pery, J.: La Casa de la Contratación y el Consejo de Indias. (Las razones de un superministerio), Ministerio de Defensa, Madrid, 1997.

17 García Fuentes, L.: El comercio español con América, 1650-1700, Diputación Provincial de Sevilla, Sevilla, 1982, págs. 23-29 y págs. 66-77; Vila Vilar, E.: "El poder del Consulado sevillano y los hombres del comercio en el siglo XVII. Una aproximación”, en Vila Vilar, E., y Kuethe, A. J.: Relaciones de poder y comercio colonial. Nuevas perspectivas, Escuela de Estudios HispanoAmericanos, Sevilla, 1999, págs. 3-34; Oliva Melgar: "La metrópoli sin territorio. ¿Crisis del comercio de Indias en el siglo XVII o pérdida del control del monopolio?” en Martínez Shaw, y Oliva Melgar (eds.): El sistema atlántico..., págs. 19-73, págs. 37-66. J. L. Velásquez Gaztelu cita una cédula de Carlos II en la que se establecía el mínimo negocio para poder ser matriculado en 200.000 maravedís cargados a riesgo propio (cédula de 24 de mayo de 1686), en Estado marítimo de Sanlúcar de Barrameda, ASEHA Cádiz, 1998 [1774], pág. 241.

18 Domínguez Ortiz, A.: La ciudad del siglo XVII, en Morales, F. (dir.): Historia de Sevilla, Universidad de Sevilla, Sevilla, 1991, pág. 92. 
como Corte regia, relación que presenta una multitud de conexiones personales y colectivas en los dos sentidos. La línea fundamental que guía estos contactos preferentes es la del reparto de competencias, de modo que cada institución sevillana encontraba amparo para la prosecución de sus objetivos en un Consejo real. Así, el Consejo de Indias solía respaldar a la Casa de la Contratación: ${ }^{19}$ la supervisión del cobro de los almojarifazgos al Consejo de Hacienda: ${ }^{20}$ por su parte, el Consejo de Castilla nombraba al Asistente, era la instancia de apelación de la Audiencias y tenía competencias en cuestiones de salida de moneda del reino, ${ }^{21}$ por último, el Consejo de Guerra participaba por derecho propio en las materias de contrabando, en el nombramiento de los generales de armadas y tenía jurisdicción sobre los delitos cometidos en el mar.

Frente a este reparto de competencias, Andalucía se erigía como una de las zonas más difíciles de someter a control fiscal por parte de la Corona. El fraude fiscal en la Edad Moderna presenta dos planos de análisis esenciales. El primero es conceptual y se relaciona con el privilegio. ${ }^{22} \mathrm{El}$ segundo es de índole práctica y tiene que ver con las formas administrativas de su persecución. Pero además, el fraude fiscal era una fuente de ingresos extraordinaria, no sometida a reglas fijas y muy rentable para la autoridad que se erigía en vigilante de esta actividad. En el caso de la Carrera de Indias podemos distinguir entre el fraude a gran escala y el practicado por pasajeros o pequeños comerciantes, cada uno caracterizado por un tipo de respuesta por parte de la Corona, como veremos.

Vistas estas disputas por el control del comercio indiano en perspectiva secular, parece claro que en el ámbito sevillano la Casa de la Contratación resultó derrotada por el Consulado, en buena medida porque la Corona se vio obligada a consentir un alto nivel de fraude en el seno del sistema. Sin embargo, esto no significa que la Corona resultase totalmente

19 AGS, CJH, 702-1-17. En una consulta del Consejo de Hacienda en 1633 sobre cierto problema de competencias, don Miguel de Ipeñarrieta hacía resumen del caso, utilizando la expresión "depende de" al referirse a ambas instituciones.

20 Ibídem. Así, al aludir a su competencia en un caso de descamino de mercadurías, remite a los dos almojarifazgos (Mayor y de Indias) y a los derechos de la cochinilla, tabaco y otros productos importados de América.

21 Ibídem. Dice al respecto que estas cuestiones tocaban al Consejo de Castilla "privativamente".

22 Cárceles de Gea, B.: Fraude y administración fiscal en Castilla. La Comisión de Millones (1632-1658). Poder fiscal y privilegio jurídico-político, Banco de España, Madrid, 1994; de la misma autora, Fraude y desobediencia fiscal en la Corona de Castilla, Junta de Castilla-León, Valladolid, 2000 . 
derrotada por los intereses de los cargadores sevillanos y obligada a claudicar en lo que sería su fin y objetivo esencial —el mantenimiento del monopolio. ${ }^{23}$ En primer lugar, porque semejante afirmación presupone que los objetivos expuestos en la creación de la Casa de la Contratación en 1503 serían los mismos que perseguía la Monarquía un siglo y medio después. Además, se olvida que la lucha contra el fraude no puede ser separada de la persecución del contrabando. El matiz entre fraude y contrabando - entendidas ambas como formas de eludir las imposiciones regias- desde luego no escapaba a los consejeros castellanos. El contrabando -que engloba tanto el tráfico de mercancías prohibidas (manufacturas de enemigos, libros, etc) como el comercio directo y fuera de todo control- era una practica al margen del sistema de flotas, mientras que el fraude se refiere a la ocultación de una parte de las mercancías negociadas dentro del sistema para evitar el pago de los derechos reales. ${ }^{24}$ En este sentido, el exceso de celo en la persecución del fraude actuaba de incentivo para el contrabando, del cual la Corona nada podía extraer, salvo en el azar de las capturas. ${ }^{25}$

¿Cómo afectaba lo que llevamos expuesto a la fiscalidad y a las rentas de los duques de Medina Sidonia? Desde la perspectiva regia — que es la que perseguía la fijación de la figura jurídica del fraude como daño al bien común o público-, la presencia de una autoridad fiscal fuerte en la puerta de las Indias podía dificultar el control fiscal en un área particularmente sensible. Sin embargo, en principio, la participación de la fiscalidad ducal en el comercio americano estaba vedada, por lo que la aduana señorial de Sanlúcar no podía registrar ni remitir mercancías al otro lado del océano. ${ }^{26}$ Ahora bien, más allá de que de facto los duques pudiesen o no despachar mercancías desde sus aduanas a Indias, todo el comercio con otros puertos atlánticos o mediterráneos incumbía plenamente a la aduana de Medina Sidonia y a la actividad de su puerto sanluqueño. En este sentido, la irrupción de América en el tejido comercial andaluz se produjo en un momento expansivo de dicho tráfico, aumentando mucho su volumen y

23 Véase Oliva Melgar: "La metrópoli...”, págs. 37-66.

24 Oliva Melgar: "La metrópoli...", págs. 39-42.

25 Ciertas prácticas implicaban las dos formas delictivas, como sucedía a fines del siglo XVI, cuando aumentó la frecuencia con la que los comerciantes sevillanos hacían viajes fuera de los convoyes de la Carrera. Consulta del Consejo de Indias denunciando la extensión de aquella práctica en AGI, Indiferente, 741, n. 254, 1-1, 28 de noviembre de 1590.

26 Decimos aduana ducal porque en Sanlúcar llegaron a convivir dos aduanas, una encargada del cobro de los Almojarifazgos Mayor y de Indias de Sevilla y otra propia del duque de Medina Sidonia. Ulloa confundió, al parecer, la aduana real de Sanlúcar con la del duque. En La Hacienda Real..., págs. 265. 
radio de acción. ${ }^{27}$ La práctica imposibilidad de controlar la circulación de mercancías fuera de registro en las inmediaciones de las costas andaluzas - tanto las cargazones a la ida como las descargas a la vuelta - implicaba que el intento de controlar esta actividad resultase un elemento clave en el reparto de poder en la ruta de las Indias. Por eso, es aquí donde hay que empezar a dar entrada a la autoridad señorial de los duques de Medina Sidonia. Para empezar, desde la perspectiva de la fiscalidad del poder señorial, cabe distinguir tres tipos de intervenciones de los duques sobre el comercio en su puerto, todas ellas susceptibles de generar beneficios.

1.-En primer lugar, la intervención jurisdiccional en la vigilancia de los delitos de fraude y contrabando afectaba a la Casa ducal en cuanto ostentadora de derechos de cobro en su propia aduana.

2.- - A esta facultad como señores jurisdiccionales se sumó, a partir de 1588, la intervención por medio del cargo de Capitanes Generales del Mar Océano y Costas de Andalucía. Este cargo dio entrada a los duques, bajo jurisdicción militar, en cuestiones de apresto de armadas y persecución del contrabando.

3.-Por último, como se verá, se acusó reiteradamente a los Medina Sidonia de, por un lado, amparar a comerciantes que practicaban el contrabando como una más de sus actividades comerciales y, por otra, de practicar ellos mismo el fraude, como veremos con más detalle. ${ }^{28}$

\section{Aspectos institucionales: aduanas y almojarifazgos}

La aduana ducal era la institución encargada del cobro del almojarifazgo sanluqueño, es decir, de los tributos pertenecientes al duque de Medina Sidonia generados por los intercambios comerciales de su villa con el exterior de la Corona de Castilla. ${ }^{29}$ Dentro del variado conjunto de las

27 Otte: Sevilla y sus mercaderes...; Bernal, M. A.: La financiación de la Carrera de Indias (1492-1824). Dinero y crédito en el comercio colonial español con América, Tabapres, Sevilla, 1992 , págs. 90-99.

28 A modo de ejemplo, se puede ver la consulta del Consejo de Hacienda que, en 1607, al tratar de las denuncias, daba a entender, como era sabido, que en el momento de salida y arribada de flotas en Sanlúcar se producían los embarques y descargas fuera de registro. 6 de abril de 1607. AGS, CJH, 474, carpeta 13, 2.1 .

29 Hacia 1616 el concepto de almojarifazgo era definido como "el derecho que pagan todas las cosas que entran y salen por la mar y comúnmente son cinco por ciento; algunas cosas hay que pagan más. Tiénese en esto la orden que todas las cosas estén apreciadas al valor que han de tener y conforme a esto se hace la valuación y para ello hay sus fieles o tasadores”. BNM, Mss 6.043, págs. 177-187, "Relación de todas las rentas...". 
fuentes de ingreso de la nobleza castellana, lo excepcional de esta renta no era el concepto —otras grandes Casas señoriales gozaban de almojarifazgos en sus villas- ${ }^{30}$ sino el hecho de que el distrito en el que se cobrase fuese un puerto de mar tan importante como Sanlúcar, caso sólo comparable, aunque a bastante distancia, con el señorío de los duques de Medinaceli sobre El Puerto de Santa María. Desde un punto de vista estadístico, es clara la importancia extraordinaria de la aduana sanluqueña en el conjunto del tesoro ducal, con un peso relativo que no hizo sino aumentar con claridad hasta 1640. Visto en perspectiva secular, el impresionante ritmo de crecimiento del producto de esta renta en la segunda mitad del XVI se mantuvo constante hasta superar la cota de los 35.000 ducados anuales en la década de 1590. De ahí en adelante, aunque se llegaron a alcanzar cifras sensiblemente superiores, lo más característico fueron unos años de relativa inestabilidad, si bien sólo en un año se registraron menos de 20.000 ducados de ingreso, nivel que se había alcanzado en 1580 . La tendencia se interrumpe abruptamente a mediados de los años de 1640, coincidiendo con la incorporación de la ciudad — que no de sus rentas- a la Corona. Con respecto al ritmo estacional del cobro en la aduana, hay que señalar la presencia de dos picos bien significativos: abril y agosto, precisamente los meses señalados como óptimos para realizar los viajes a Nueva España y Tierra firme, respectivamente. ${ }^{31}$ Hay que señalar también que todo este ingreso fue administrado de forma directa por los Medina Sidonia, ya que nunca pusieron su aduana en arriendo, tanto por razones de prestigio como de cálculo económico. ${ }^{32}$

Aunque con el tiempo se produjo una diversificación de los conceptos percibidos en la aduana ducal, desde el punto de vista conceptual, la parte del león se la llevaba el famoso almojarifazgo sanluqueño que, como renta más característica de la Casa de Medina Sidonia, era muchas veces confundida con la aduana en su conjunto. El origen de esta renta fue la concesión a don Alonso Pérez de Guzmán el Bueno del derecho de carga y descarga de naves en su puerto, al mismo tiempo que se le entregaba el señorío sobre

30 Tal es el caso de los duques de Osuna en la villa homónima. Atienza Hernández, I.: Aristocracia, poder y riqueza en la España moderna. La Casa de Osuna, siglos XV-XIX, Siglo XXI, Madrid, 1987, págs. 279-281.

31 Comellas: Sevilla, Cádiz..., pág. 180.

32 Así, hacia 1580 el duque ordenó elaborar un informe para la evaluación de cierta propuesta que había recibido para el arriendo de su aduana. La conclusión tajante del mismo era que el duque podía perder "incomparablemente más" con el arriendo que si lo mantenía bajo su administración. ADMS, 1.019. 
la villa, en $1297 .{ }^{33} \mathrm{El}$ notable desarrollo comercial de toda la zona a lo largo de la Baja Edad Media provocó constantes roces con los almojarifes de Sevilla — ministros encargados del cobro del Almojarifazgo Mayor-, obligando a los duques a obtener sucesivas confirmaciones de su renta. ${ }^{34}$ En el trasfondo encontramos el intento frustrado de los ministros sevillanos de caracterizar el almojarifazgo de Sanlúcar como una parte desgajada de la renta que a ellos competía. En tiempos de Fernando el Católico volvieron a colisionar ambos rangos de almojarifes — reales y señoriales-, si bien, pese a los problemas que hubo entre dicho monarca y el conde de Ureña - tutor del heredero del ducado-, los derechos señoriales fueron confirmados en 1512 y $1513 .{ }^{35}$

De todos modos, en las décadas siguientes la demanda de los almojarifes sevillanos fue encontrando un claro eco en la aspiración de la Corona por hacer que los niveles de imposición que regían el Almojarifazgo Mayor de Sevilla - que oscilaban entre un máximo del 10 y un mínimo del $2{ }^{\prime} 5 \%$ - ${ }^{36}$ se aplicasen en todos los puertos de la Baja Andalucía. Por su parte, la tabla de la aduana ducal al comienzo de nuestro periodo establecía el pago de un $5 \%$ de entrada y un $2{ }^{\prime} 5 \%$ de salida. ${ }^{37}$ Sobre este punto crucial, el duque defendió que la rebajas que él pudiera hacer sólo afectaban a su propia hacienda, por lo que debían ser consideradas como simples mercedes contra el tesoro ducal. Por el contrario, esta cuestión fue el gran caballo de batalla entre Cádiz, Sevilla y Sanlúcar a lo largo de todo el siglo XVI.

Profundizando en el conocimiento de la aduana señorial, debemos señalar que, según la contabilidad de los duques, a principios del siglo XVII se cobraban en dicha aduana, junto al almojarifazgo en sentido estricto, otros dos conceptos: la alcabala de la aduana y la cobranza de los mer-

33 Existen varias copias impresas del privilegio de donación de Sanlúcar, una de ellas en ADMS, 1.014; algunas confirmaciones reales del siglo XIV en AGS, Varios-Medina Sidonia, caja 5, n. ${ }^{\circ} 84,9$ de agosto de 1365. Ver también Velásquez Gaztelu: Estado marítimo..., págs. 85-86; Solano Ruiz, E.: "La hacienda de las Casas de Medina Sidonia y Arcos en la Andalucía del siglo XVI", Archivo Hispalense, 168 (1972), págs. 85-176.

34 Una de las últimas tuvo lugar en 1460, cuando Enrique IV concedió la plenitud de cobro de estos derechos al II duque don Enrique, como agradecimiento por la pacificación de Sevilla. Del hecho de que este documento tuviera título de concesión desprende Moreno Ollero que el almojarifazgo estuvo fuera de la Casa, aunque no hay prueba de ello. Sanlúcar..., págs. 198-199.

35 Para la confirmación, el rey se apoyó en el testimonio de varios mercaderes genoveses, flamencos e ingleses que aseguraban la inmemorial posesión del duque de esta renta. Moreno Ollero: Sanlúcar..., pág. 199.

36 Ulloa: La Hacienda Real..., pág. 266.

37 ADMS, 3.987, "Memorial de lo que Sevilla [...] ha pretendido, hecho y pedido en Sanlúcar". 
caderes bretones. El primero, aunque algo oscuro, se basaba en la tasación de los intercambios comerciales de algunos productos que se registraban en la aduana para su salida de la ciudad. Da la sensación de que el cobro se realizaba por medio de un evalúo o tasación global de las mercancías que eran embarcadas en los tornaviajes de los mercaderes extranjeros, de modo que vendría a ser un almojarifazgo de salida. Sin embargo, la alcabala no era igual para todos los productos que pasaban por la aduana, sino que aquí la doble distinción entre lo que pagaban los mercaderes castellanos y los extranjeros, de una parte, y lo que se pagaba en función del punto de destino, por otra, marcaba considerables diferencias. De este modo, la alcabala de la aduana otorgaba a los duques una herramienta de proteccionismo señorial para favorecer la producción — sobre todo de vino- en el propio territorio mediante el mayor encarecimiento porcentual del producto elaborado fuera..$^{38}$

Por su parte, la llamada "cobranza de los mercaderes bretones" era una imposición que aparece por primera vez como tal en los primeros años del siglo XVII y que desaparece tras el proceso al IX duque de 1641-1645. Se trataba de una imposición genérica que pagaban los mercaderes bretones y, al parecer, los extranjeros en general, para poder comerciar en Sanlúcar ${ }^{39}$ Es muy probable que el cobro de esta renta tenga su origen en una obligación que, según Velázquez Gaztelu, tenían los bretones, por acuerdo tomado con el duque, de cargar en sus tornaviajes al menos la tercera parte de sus barcos con vinos de Sanlúcar. El acuerdo habría estado vigente al menos entre 1568 y 1589, aunque, según este cronista, hubo quejas de los productores sanluqueños por incumplimiento por parte de los bretones. Por eso, la aparición diez años después de la cobranza cabe ser interpretada como forma de compensación al duque por la anulación del acuerdo anterior. ${ }^{40} \mathrm{El}$ mantenimiento del término bretones en esta renta — aun admitiendo que pudieran seguir siendo mayoritarios los comerciantes de la Bretaña $-{ }^{41}$ puede provenir tam-

38 Hay que señalar también que en ocasiones la misma estructura de cobro de la aduana era utilizada para la percepción de algunos otros ramos fiscales, como la alcabala percibida por la venta de censos y posesiones o la alcabala del aceite y del vino que se exportaba, que a veces figuran como renta aparte y no inclusa en la categoría de alcabala de la aduana

39 El nombre deriva del predominio de los mercaderes franceses en Sanlúcar que, según describía en verso el padre dominico fray Pedro Beltrán,"Los Surtos vasos membrudos/ parecen islas francesas/ llenos de árboles desnudos/ a quien las jarcias espesas/ sirven de ramos menudos". Beltrán, P. F. P.: La Charidad guzmana, Sanlúcar de Barrameda, 1948 [1612], pág. 26.

40 Velásquez Gaztelu, J. L.: Historia antigua y moderna de la muy noble y muy leal ciudad de Sanlúcar de Barrameda, ASEHA, Sanlúcar, 1994 [1760], pág. 347. 
bién del espacio físico que en Sanlúcar concentraba la mayor parte de las tiendas y comercios de exportación, que era la calle Bretones. De ser esto cierto, la novedad consistiría ante todo en que se trataba de una renta que gravaba por mayor la exportación de producciones locales. ${ }^{42}$ Cuantitativamente, el crecimiento de la cobranza fue opuesto al descenso de los otros dos ramos que se percibían en la aduana, llegando a ser la parte más importante de lo percibido en Sanlúcar.

\section{Planteamiento de una disputa}

Un memorial que data de hacia 1585 conservado en la British Library recoge por extenso y con gran profusión de datos todo un catálogo de las contravenciones a la legislación regia que, según denuncia, eran amparadas por los Medina Sidonia en su puerto de Sanlúcar. ${ }^{43}$ Probablemente dirigido al Presidente del Consejo de Hacienda, este texto debe ser inscrito en los esfuerzos del Consulado de Indias por alzarse con el arriendo de los dos almojarifazgos sevillanos - Mayor y de Indias-, objetivo para el cual resultaba conveniente hacer una crítica a fondo del statu quo ante en todo el distrito. Por esta razón, y pese a que su autor demuestra conocer sobradamente la materia, la clara finalidad instrumental de la denuncia nos debe llevar a valorar con cuidado algunos de los extremos aludidos. Sin embargo, tanto por la amplitud del contenido como por su carácter interesado, nos va a servir para situar los términos en los que se produjeron las fricciones de las que nos vamos a ocupar.

En un plano teórico, comienza el texto afirmando que el almojarifazgo ducal sólo competía a los productos que entrasen y saliesen del reino por mar. Distinguía así esta renta de los derechos de portazgo, los cuales vincula en exclusiva a la hacienda regia. ${ }^{44}$ Por el contrario, los Medina Sidonia,

41 Aunque no se refiera a Sanlúcar, es indicativo del grado de fluidez de las redes comerciales bretonas con Andalucía el estudio de Broens, N.: Monarquía y capital mercantil: Felipe IV y las redes comerciales portuguesas (1627-1635), Universidad Autónoma, Madrid, 1989.

42 Hasta tal punto era importante la actividad que se concentraba en la calle Bretones que, tras el destierro de Sanlúcar del IX duque don Gaspar, la duquesa - aún residente en su palacio- hubo de proponer el nombramiento de un alcalde específico para la calle de los Bretones, con el fin de que los problemas de autoridad no perjudicasen aún más el trato que allí tenía lugar. ADMS, 4.067, fol. 410, 1642.

43 BL, Add, 28.369, 188r-189v.

44 Corriendo de entrada, para los productos negociados por extranjeros, al 5\%, para los vecinos de Sanlúcar al $4 \%$ y para todos ellos al 2’5\% de salida de la ciudad. 
apoyados en el "mucho respeto" que les tenían los almojarifes de Sevilla, habrían ido negociando con estos la permisión de cobrar el mismo derecho sobre las mercancías que entrasen por tierra a un porcentaje, además, muy bajo. A lo que no se atrevía el autor era a cuantificar el procedido:

"Que estos derechos de entrada y salida dicen valen mucho al duque, de que no se ha podido tomar relación cierta, pero si fuese verdad que le valen la mitad de lo que se dice, se entendería que las mercaderías que vienen por tierra son en gran cantidad, y no entran para consumirse en Sanlúcar, sino para cargarse para las Indias sin pagar derechos de almojarifazgo de Indias [...]".

Esta práctica implicaría otros daños para la Real Hacienda, como sería la pérdida de los derechos de entrada en América y del procedido de la persecución de las cosas vedadas - materia sobre la que, aún peor, el denunciante hacía pesar una acusación de encubrimiento consciente por parte de los oficiales del duque.

Desde otro punto de vista, el informe denunciaba que todos los años había en Sanlúcar dos ferias o períodos francos, llamados "vendeja" —entre septiembre y noviembre- y "racavendeja" — febrero y marzo-, en el transcurso de las cuales se bajaban al $2 \%$ los derechos que los extranjeros pagaban por importar textiles, a lo que no se añadía alcabala alguna de salida por tierra. ${ }^{45}$ Según nuestro texto, en estas ferias muchos mercaderes de la comarca se abastecían para todo el año. El valor para el duque de estos períodos francos era estimado en ocho millones de maravedíes, lo que suponía un volumen de negocio en la feria de unos 400 millones. La consecuencia de nuevo era el daño a las aduanas reales de Cádiz y Sevilla, porque la expectativa de un menor precio desviaba este comercio hacia Sanlúcar. A ello se sumaba el hecho de que los ministros de la aduana del duque no abriesen los fardos de los extranjeros para inspeccionarlos, motivo que hacía preferible aquel puerto señorial. Este trato de favor sería aún mayor para franceses en general y bretones en particular, tanto que "con esto los bretones tienen a Sanlúcar por sus Indias". ${ }^{46}$ En efecto, el anónimo denunciante recogía el acuerdo al que aludimos entre los bretones y el duque para la cargazón de vinos de Sanlúcar, añadiendo el dato de que, a cambio, los de esta nación tenían garantizado todo el año una baja de dere-

45 Según Moreno Olleros desde comienzos del siglo XIV, época de gran expansión del cultivo del vino en toda el área ya existían unas ferias llamadas "vendejas" en Sanlúcar. En Sanlúcar..., pág. 204.

$46 \mathrm{BL}$, Add, 28.369, 188r. 
chos que reducía al 2\% la entrada y al 3\% la salida. Con esta acusación se ampliaba notablemente el margen de influencia que se presuponía al duque y se daba entrada de lleno al aspecto territorial de su poder. Para colmo, todo aquel volumen de negocio implicaba la salida de grandes cantidades de moneda del reino a manos de mercaderes franceses en pago de los textiles importados. ${ }^{47}$

Este estado de cosas suponía un flagrante incumplimiento de las disposiciones reales que obligaban a no hacer gracias so pena de perder las rentas. En efecto, una cédula de Carlos V fechada en 1526 - que instaba a establecer en todos los puertos del distrito del Almojarifazgo Mayor de Sevilla las tablas que fijaban los derechos regios y prohibían las rebajasfue pregonada en Sanlúcar, aunque de inmediato encontró la oposición del duque, que hizo saber, mediante otro pregón, que se comprometía a impedir a los almojarifes de Sevilla llevar a efecto la real cédula. Frente a las amenazas de la real disposición, el duque aseguraba su protección a los mercaderes extranjeros de su puerto para evitarles tributar en Sevilla, comprometiéndose incluso a tomar a su cargo la defensa legal de los afectados. ${ }^{48}$ Que medio siglo después se siguiera debatiendo la materia prueba que la real cédula no se había cumplido. Es más, advertía nuestro autor de que, tras la toma del arrendamiento del Almojarifazgo Mayor por el concejo de Sevilla, en 1573, el duque había negociado con dicho cabildo una moratoria para que no se cumpliese la cédula. Aquel fruto de la "mucha mano" que el duque tenía en el cabildo hispalense explicaba por sí solo que ni los arrendadores del almojarifazgo ni el duque quisieran que residiera en Sanlúcar ninguna justicia regia. ${ }^{49}$

Por otra parte, denunciaba abusos jurisdiccionales por parte de los ministros del duque, el más grave de los cuales consistía en que todos los barcos que entraban en la barra de Sanlúcar, aunque su destino fuese otro puerto, eran detenidos por una barqueta ${ }^{50}$ con un oficial de la aduana ducal que inspeccionaba los libros con objeto de persuadir a los maestres para que descargasen alguna parte en aquel puerto, presionándoles de modo que,

47 Calculaba que, si la entrada de ropa alcanzaba el valor de 400 cuentos durante las ferias, la carga de vino en el tornaviaje no alcanzaría más de los 10.000 ducados en valor, de modo que todo el resto iría en moneda labrada o lingotes de plata.

48 Moreno Ollero: Sanlúcar..., págs. 200-201.

49 BL, Add, 28.369, 188v.

50 Se trata de un pequeño navío que utilizaban los ministros de las aduanas en los puertos de mar para inspeccionar los navíos que entrasen en su jurisdicción. 
si no lo obtenían, los detenían para causarles molestias. A ello se sumaban los intentos de hacer pagar derechos de ondeaje - operación consistente en transbordar mercancías de un barco de mayor tonelaje a otro de menor calado para llegar con seguridad a Sevilla—. En resumen, según este texto, se estaba dando lugar a que mercaderes de lugares realengos como Cádiz se asentasen en Sanlúcar para mayor comodidad de sus negocios, dado que ya incluso los barcos procedentes del Mediterráneo, que según el denunciante nunca lo habían hecho antes, acudiesen a aquel puerto en lugar de a los realengos. En consecuencia, Sanlúcar quedaba "en poco tiempo muy crecido y de gente muy rica". ${ }^{51}$

En el capítulo de las cosas vedadas aún insistía el informe en que, para poder defraudar mejor, los mercaderes extranjeros remitían la mayor parte de las mercancías prohibidas a Sanlúcar a nombre de los principales ministros ducales para obtener amparo y favor. Así, aunque alguna justicia regia tratase de descaminar las mercaderías, los ministros del duque salían al paso diciendo que primero debían entender ellos la causa sobre el impago de derechos en Sanlúcar, de modo que lograban ocultar el fraude. Todavía el duque era acusado de fomentar el cohecho practicado por un cónsul de los bretones:

\begin{abstract}
"se dice que los extranjeros usan por mano de Hernando Caballero, cónsul de los bretones, un soborno que [consiste en que] cuando algún juez o ministro de Su Majestad averigua el daño y fraude que allá recibe su Hacienda, hace un repartimiento entre los dichos extranjeros de la cantidad que le parece es menester para cohechar y tener gratos a los tales jueces y ministros sobre las mercaderías que han metido y entiéndese que esto sale del duque, porque también él los granjea y regala, a fin de acrecentar el trato de Sanlúcar".
\end{abstract}

En consecuencia, el memorial denunciaba que los jueces reales no lograban nunca averiguar nada al quedar enredados en la maraña de ocultamientos y sobornos. Para el remedio de todo aquello proponía que se instalase una aduana real en Sanlúcar, en la cual se aforasen y registrasen todas las mercancías, de modo que el rey cobrase lo que le correspondía y el duque lo suyo. ${ }^{52}$

Sin duda este documento ofrece una visión sumamente interesada y exagerada sobre el reparto del comercio en Andalucía, pero señala dos puntos esenciales para comprender la importancia de Sanlúcar de Barrameda

51 BL, Add, 28.369, 188v.

52 BL, Add, 28.369, 189r-v. 
en el conjunto de la Monarquía Hispánica: por una parte, que aquel puerto era un competidor activo en la atracción de mercaderes y comerciantes, tanto con Indias como con otros destinos, y por ende una notable fuente de rentas; y, por otro lado, que la capacidad de penetración de las justicias regias en el señorío más poderoso de Castilla era, cuanto menos, compleja. Más allá de excesos en las acusaciones, tener aduana propia permitía al duque y a los grandes productores sanluqueños vender sus productos agrarios en los tornaviajes. ${ }^{53}$ Pero, sobre todo, los productos de importación dan una indudable dimensión transoceánica al trasiego comercial sanluqueño. De este modo, la participación de los Medina Sidonia en aquel tráfico adquiere su dimensión fiscal al convertirse Sanlúcar en un importante mercado para los cargadores a Indias, sobre todo de textiles. En cuanto a las conexiones de Medina Sidonia con el cabildo hispalense, nos consta que en nuestro período algunos veinticuatros - o sus parientes - entraron al servicio ducal, como agentes en Madrid o como representantes en diversos modos..$^{54}$

\section{La evolución del sistema: el equilibrio improbable}

El padre Beltrán cantaba a Sanlúcar refiriéndose a ella como "aquella franca ciudad/ libre de todos derechos/ que sólo a Su Majestad/ dos años le pagó pechos/ por verle en necesidad". ${ }^{55}$ No sabemos a qué dos años se refería el dominico en estos versos, aunque la franqueza total de la ciudad, hacia 1612, era una exageración. No obstante, es cierto que Sanlúcar había permanecido virtualmente exenta de las imposiciones regias hasta las postrimerías del XVI gracias a la enconada oposición que a las novedades institucionales ofrecieron los duques. De aquellos intentos regios y de la resistencia de la jurisdicción ducal es de lo que nos vamos a ocupar a continuación.

53 Según Moreno Ollero, ya a comienzos del XVI había una fuerte competencia por comercializar la producción vinícola entre Jerez, el condado y la propia Sanlúcar — junto con la villa vecina de Trebujena-, área esta última que conoció el mayor incremento de todas en las primeras décadas de la centuria del Quinientos. En Sanlúcar..., págs. 204-205.

54 En 1631, cuando el duque nombró su agente en Sevilla a don Juan de Vallejo y Solís, que era primo de don Juan de Vallejo y Velasco — regidor-, éste firmó una escritura y compromiso de fianza del oficio de su primo hasta un máximo de 2.000 ducados. ADMS, 3.094, 12 de diciembre de 1631

55 Beltrán: La Charidad Guzmana..., pág. 14. 


\section{Hacia el control externo en el comercio indiano: las visitas (1576-1600)}

En el medio siglo posterior a la publicación de la cédula de 1526 — que, recordemos, perseguía igualar los derechos de aduana-, los intentos por parte de la Monarquía de intervenir en la gestión fiscal del comercio exterior en Sanlúcar de Barrameda fueron más bien tímidos. Felipe II confirmó el contenido de la cédula en 1562, aunque aún no dotó al comercio sevillano de instrumentos precisos para hacerla cumplir. Cuatro años más tarde, una nueva cédula de Felipe II acrecentó los derechos percibidos sobre la exportación por mar de todos los productos y mercaderías. ${ }^{56}$ Aquella nueva regulación suponía la creación de tablas que distinguían las diversas mercaderías e implicaba una estructura de control algo más compleja que la precedente, todo lo cual fue dando paso a graduales intentos de control aduanero en todo el complejo y discontinuo distrito de la Baja Andalucía, aunque de momento afectó poco a Sanlúcar. ${ }^{57}$

En este contexto, un viejo expediente institucional - como era la escribanía de sacas y cosas vedadas, creada sobre el papel en 1512 con competencias muy amplias - ofreció a la Corona la posibilidad de obtener, por un lado, dinero de su arriendo y, por otro, un nuevo instrumento de control sobre el comercio. Consistía el oficio en la competencia para registrar todas las mercancías que entrasen o saliesen del reino y que debiesen derechos de aduana pudiendo descaminar, quien lo detentase, aquellas que no hubiesen satisfecho lo debido. En 1576 un individuo llamado Pedro Negrete presentó un arbitrio a Felipe II - por medio de la Cámara de Castilla - solicitando la rehabilitación de aquel oficio de nuevo en su persona. Negrete recordó los términos en los que fue concedido al primer poseedor, el doctor Lorenzo Galíndez de Carvajal, para solicitar que ahora se ampliase la jurisdicción, que antes abarcaba la costa entre Gibraleón y Cartagena, a toda la Corona de Castilla. Haciendo memoria del desenvolvimiento de la escribanía, recordaba Negrete que hubo de ser litigado su ejercicio por los tenientes del oficio en cada lugar donde se

56 Aunque en diversa cuantía: ciertos productos pasaron de pagar el 2'5\% de derechos que al principio pagaban todos los productos al $10 \%$ (entre ellos la cochinilla, corambres, aceitunas y frutos secos); otros subieron al 7'5\% (sedas, vinos, perlas y piedras preciosas), quedando el resto de los no citados en un $5 \%$.

57 Se citaban aduanas de cobro del almojarifazgo de Sevilla — sólo en los obispados de Sevilla y Cádiz - en Jerez, Cádiz, Sanlúcar, El Puerto de Santa María, condado de Niebla, marquesado de Gibraleón y Lebrija. 
debía ejercer, de lo que al fin se entendió "solamente han sido admitidos [...] en la ciudad de Jerez y villa de El Puerto de Santa María". ${ }^{58}$ Además, Negrete acusaba a los administradores del Almojarifazgo Mayor de Sevilla de haberse concertado con los dueños del oficio para que, a cambio de cierta cantidad, no siguiesen tratando de ponerlo en ejercicio. El argumento de Negrete era claro: sólo con que se aplicase de veras el oficio al conjunto del arzobispado de Sevilla pasaría a multiplicar su valor al menos por tres, perjudicando sólo a quien entonces los poseía, a la sazón Pedro Hernández Roldán. Por el contrario, causaría un gran beneficio en las aduanas reales, porque del hecho de que en la práctica lo administrasen los arrendadores del almojarifazgo o sus delegados se derivaba que se despachasen muchas cosas vedadas "y se asientan en los libros confusamente y con poca claridad". Especialmente señalaba la extensión de aquella mala práctica en el obispado de Cádiz. La Cámara no llegó aquel año a ninguna conclusión, dada la división de pareceres, por lo que el rey mandó hacer mayores averiguaciones. ${ }^{59}$

Como resultado, al año siguiente Felipe II solicitó la opinión del contador Garnica, quien respondió que no encontraba grandes inconvenientes, sino que

"antes me parece que será útil dársele [a Negrete], pues ahora no le tiene nadie por título de Su Majestad y hará que le acabe de asentar y allanar a los escribanos de los puertos y pueblos donde lo hubiere de usar y poner tenientes, en que habrá de tener muchos pleitos, costas y gastos, y hecho esto podrá ser para adelante buen oficio".

Esta declaración, que no deja dudas sobre el carácter construido - más que creado - de los oficios regios, demuestra las múltiples resistencias que cualquier innovación institucional generaba en los sectores implicados en el comercio atlántico, cuyos privilegios podían estorbar judicialmente la ejecución de la voluntad regia. Por su parte, la propia Cámara de Castilla se opuso al oficio en su segunda consulta, desestimando la petición de Negrete y aconsejando que se creasen escribanías para cada puerto, lo cual conllevaría un mayor provecho para la hacienda regia. El rey, sin embargo, anotó que le parecía bien la petición de Negrete, siempre que rentase al menos 2.000 ducados destinados a los arqueros de Sevilla. ${ }^{60}$ De

58 En Jerez, sólo en lo referente a las aduanas y diezmos, mientras en El Puerto también se ejercía sobre las cosas vedadas

$59 \mathrm{BL}$, Add, 28.369, 2r-3r, 9 de septiembre de 1575.

$60 \mathrm{BL}$, Add, 28.369, 9r-10v, entre el 26 de junio de 1576 y el 23 de junio de 1577. 
hecho, aunque no hemos encontrado el nombramiento, Negrete obtuvo lo que pedía hacia 1580.

Los modestos precedentes de aquel cargo señalaban como sus principales opositores a los almojarifes de Sevilla, que se negaron a reconocerlo. Pero con la ampliación de las causas que competían al escribano de sacas a toda forma de exportación que no pagase derechos, las resistencias aumentaron. De hecho, tal expansión produjo problemas de territorialidad, asunto en el que los Medina Sidonia entraron de lleno. En efecto, el VII duque, don Alonso Pérez de Guzmán el Bueno, se negó a reconocer la competencia de la escribanía en la aduana de Sanlúcar, alegando que sólo atañía al Almojarifazgo Mayor de Sevilla. ${ }^{61}$ En 1584 se falló una sentencia por parte del Consejo de Castilla que, interpretada por los abogados del duque, significaba que al ser la de Sanlúcar una aduana de señorío, el cargo de escribano de sacas que ostentaba Negrete sólo debía entenderse respecto a los llamados derechos acrecentados - es decir, los productos obligados al pago de derechos de aduana en 1566- y no a todas las sacas. Más aún, alegaban los abogados del duque que, teniendo en cuenta que Felipe II había ordenado crear en Sanlúcar una aduana específica para la cobranza de los nuevos derechos - en la que se había colocado ya a un factor-, se entendía que nada nuevo tenía que hacer Negrete en Sanlúcar. ${ }^{62}$

No obstante, Negrete obtuvo el respaldo del Consejo de Hacienda, con cuyas provisiones acudió de nuevo a Sanlúcar para tratar de hacerlas cumplir. Sobre el terreno, Negrete volvió a encontrar la sistemática y cerrada oposición de los jueces de la aduana del duque. El relato de sus desvelos es muy significativo. Un informe del abogado de Negrete narraba cómo en 1587, al enviar al enésimo teniente del oficio a Sanlúcar, apoyado por el alcalde mayor de Cádiz — Gonzalo de Mesa—, los almojarifes del duque le habían contestado "que tenía que se cansar en hacer las cédulas e despachos tocantes al dicho oficio". Y en efecto, una vez que se hubo marchado Mesa, cuando el teniente de escribano quiso ejercer su oficio, los ministros del duque

"se lo habían resistido e impedido, cerrando las puertas de la dicha aduana [ducal] y no se habían querido juntar con el dicho Pedro de Ledesma a despachar las mercadu-

61 En concreto, se hizo contradicción a las pretensiones de Pedro Negrete, segundo poseedor del cargo, en su intento de ser también escribano de la aduana de Sanlúcar. ADMS, 1.014.

$62 \mathrm{El}$ texto al que remitimos es el parecer de los doctores Berasategui y Asensio López, emitido en febrero de 1585, que ofrecían a la consideración de otro colega, todo ello en preparación de la llegada de Negrete para pedir cumplimiento de la sentencia del Consejo. ADMS, 1.014. 
rías que venían a la dicha aduana, ni dejarle usar del dicho oficio [...]. Por manera que después de haber llevado cinco jueces de comisión por nos proveídos a costa de su parte a la dicha villa de Sanlúcar [...], estaba el dicho su parte despojado, como al principio que había principiado a litigar". ${ }^{63}$

De aquellas disputas se derivó una acusación criminal por prevaricación, firmada por el titular de la escribanía, contra varios ministros de la aduana ducal. Del mismo año 1587 data también un auto por el que Mesa, por mandato y delegación del Consejo de Castilla, conminaba al acatamiento del oficio y de las sentencias presentadas por los tenientes de Negrete, so pena de pérdida del cargo y multa de 2.000 ducados. Sin embargo, el duque interpuso recurso.

Aunque los autos a que dio lugar esta fase de la disputa no nos constan, sabemos que tres años después, en enero de 1590, se remitió a Sanlúcar a un nuevo juez de comisión, Pedro Gago de Castro, para volver a intentar poner en ejercicio el oficio. En sustancia Negrete solicitaba que se le repusiera sin más en el uso de su oficio al amparo de las sentencias y autos de que ya disponía, mientras el duque, por el contrario, sostenía que la escribanía de sacas se estaba litigando sin perjuicio de la posesión por su parte de ciertos oficios incompatibles, por lo que no tenía sentido dar este cargo sin que el otro pleito concluyera. No obstante, el 5 de enero Gago mandó que, pese a las alegaciones de Medina Sidonia, se cumpliese lo mandado por el rey a favor de Negrete. Para ello acudió en persona a la aduana del duque, donde se encontraban despachando los almojarifes del rey -Pedro Echeum y Antonio López de León y Yañez-, el administrador de las aduanas del duque - Francisco Gutiérrez de Valbuena-y los almojarifes ducales -Estacio de Figueredo y Bartolomé Juárez-, en presencia de los cuales Gago llamó al procurador de Negrete - Juan Núñez de Bohórquez-y a la parte del duque, ante los cuales puso en posesión del oficio a Hernando de Mayorga - escribano de El Puerto de Santa María, nombrado por Negrete como su teniente-, con apercibimiento de que no se le molestase ni inquietase. Los tres ministros ducales dijeron lo obedecerían con el acatamiento debido y pusieron la orden sobre sus cabezas, diciendo que tendrían a Negrete o sus tenientes por escribano de sacas, diezmos y aduanas, todo ello "sin perjuicio del derecho que el duque de Medina [Sidonia] tiene a la dicha escribanía". Del mismo modo, Gago hizo notoria aquella posesión a otros jueces del duque, entre ellos el corregidor de Sanlúcar. ${ }^{64}$

63 ADMS, 1.014, carta de 6 de enero de 1590.

64 ADMS, 1.014, autos y ejecutoria de 6 de enero de 1590. 
Así, tras más de 80 años, se lograba poner en práctica un oficio que era visto por los Medina Sidonia como una clara injerencia en su ámbito fiscal, aunque, como veremos, ciertas circunstancias permitieron dar un vuelco a la situación pocos años más tarde.

Ahora bien, la escribanía difícilmente hubiera podido imponerse si no se hubiera emprendido, al mismo tiempo, la tarea de desarrollar las cédulas de 1526 y 1566 , en las que se contemplaba la creación de una completa estructura aduanera regia - hasta entonces inexistente- en todos los puertos andaluces, incluidos los de señorío. Medina Sidonia trató de defender su espacio fiscal por medio de una demanda a la Corona en el tribunal de la Contaduría Mayor de Hacienda contra la cédula de 1566, alegando que el crecimiento de los derechos de almojarifazgo en Sanlúcar y su partido le pertenecían a él en virtud del derecho de concesión de dicha renta, de igual modo que reclamaba su derecho a hacer rebajas y mercedes. Sin embargo, la causa dio un giro cuando en 1567 Pedro Luis Torregrosa tomó el arriendo del almojarifazgo Mayor de Sevilla y trató, en consecuencia, de poner aduanas regias en todo el distrito, incluida Sanlúcar — en concreto en el paso llamado de la Barraca-. La excusa de Torregrosa para introducir esa novedad fue que por aquel paso - que se encuentra en la orilla oeste del Guadalquivir, una legua y media río arriba de Sanlúcar - se introducían mercancías sin pagar derechos en perjuicio de la recién creada aduana real de Lebrija. El duque se opuso abiertamente, acusando a Torregrosa de hacer él mismo gracias y sueltas, entre otros a los propios vecinos de Lebrija. La disputa no pasó a mayores al alcanzar ambas partes un acuerdo particular según el cual, por un lado, desde la aduana de Sanlúcar se despacharían a todas las aduanas dependientes del arriendo de Torregrosa las mercadurías a ellas consignadas, mientras, por otro lado, el duque podría hacer pasar por la Barraca sin pagar Almojarifazgo Mayor —en dirección al condado de Niebla - mercancías hasta un valor de 12 millones de maravedíes. Los encargados de vigilar el cumplimiento de esta parte del acuerdo serían dos almojarifes enviados por cuenta de Torregrosa. Aquellos ministros llevarían barqueta y guardas y las causas que descubriesen se llevarían ante la justicia ducal de Sanlúcar, asignando las condenas en metálico a la cámara señorial cuando el culpable defraudase sus derechos, o a la Cámara de Castilla si iban contra el Almojarifazgo Mayor de Sevilla. Tal acuerdo fue ratificado con los nuevos arrendadores de esta renta, el cabildo de Sevilla, por el tiempo que tuvieron a su cargo el almojarifazgo — de 1573 a 1580 - , salvo en lo que respecta al valor de lo que se podría pasar 
por la Barraca, reducido primero a seis y luego a cuatro millones de maravedíes. ${ }^{65}$

Como en principio todo esto sólo afectaba al Almojarifazgo Mayor de Sevilla, no fue hasta 1580 -momento en el que se comenzó a contemplar la posibilidad de arrendar juntos los dos almojarifazgos hispalenses, Mayor y de Indias - cuando aparecieron los primeros grandes problemas entre la autoridad de Medina Sidonia y la jurisdicción de los arrendadores de estas rentas, precisamente porque el rey, espoleado por la necesidad de obtener más fondos, comenzó a respaldar activamente las nuevas pretensiones de los arrendadores a través del Consejo de Hacienda — presidido por Hernando de Vega $-{ }^{66}$ mediante el envío de jueces visitadores desde la Corte. De hecho, como las irregularidades no eran exclusivas de Sanlúcar, la disputa trascendió ya abiertamente el nivel local para convertirse en una investigación general sobre el comercio en Andalucía. Así, tras el fracaso, a principios de los años de 1580, del arriendo de los dos almojarifazgos por parte de Juan Alonso de Medina y consortes - entre los que se encontraban el prior y cónsules de Sevilla-, ambas rentas se hubieron de poner de nuevo en subasta, como resultado de la cual el cabildo hispalense se alzó con ambos almojarifazgos por una década. ${ }^{67}$ En este marco de cierta reorganización en la percepción de derechos comerciales en Andalucía es en el que se inscribe la primera gran visita general a los puertos dotados de aduana dentro del partido del doble almojarifazgo. Tanto la unión de las dos rentas como la visita fueron medidas dirigidas a aumentar el ingreso mediante el control del creciente fraude en el comercio con Indias.

La pauta de toda la serie de visitas a Sanlúcar que se sucedieron en las décadas siguientes la marcó en 1581 el teniente de asistente en Sevilla - el doctor Ortiz de Caicedo- al fundar de forma efectiva, aunque efímera, la primera aduana regia en el distrito sanluqueño, de nuevo en el paso de la Barraca. Sin embargo, apenas hubo abandonado la ciudad, su labor quedó en nada, por lo que en 1584 se remitió al licenciado Luis Romero - dotado de vara de justicia y de un equipo de colaboradores-

65 ADMS, 3.987, todo ello aparece resumido en un texto redactado como instrucción a un abogado del duque, titulado "Memorial de lo que Sevilla [...] ha pretendido, hecho y pedido en Sanlúcar de Barrameda".

66 Carlos Morales, C. J. de: El Consejo de Hacienda de Castilla, 1523-1602: patronazgo y clientelismo en el gobierno de las finanzas reales durante el siglo XVI, Junta de Castilla-León, Valladolid, 1996, págs. 134-139.

67 Lorenzo Sanz, E.: Comercio de España con América en la época de Felipe II, Diputación de Valladolid, Valladolid, 1986 [1979], tomo II, págs. 399-403. 
con el propósito de rehacer lo logrado y averiguar lo ocurrido en la Barraca. ${ }^{68} \mathrm{Al}$ parecer, la fundación de una aduana real en la venta de la Barraca - dotada de las armas reales, puestas en lugar visible- fue desmantelada por algunos ministros ducales que, amparados por una escolta, desalojaron a los almojarifes y quitaron las armas reales. El duque, por su lado, denunció que los almojarifes enviados por Sevilla habían violado los acuerdos y comenzado a hacer vejaciones para ahuyentar a los comerciantes de Sanlúcar y obligarlos a acudir a otros puertos. Más grave aún era que, según el duque, pese a que el cometido de los almojarifes sevillanos sólo competía a la salida de mercadurías por mar — que eran las acrecentadas por la cédula de 1566 - hubiesen procurado aumentar también los derechos de entraba y los de salida por mar y tierra. Según él, tal actitud era una provocación injustificada para desatar su ira. ${ }^{69}$

Más allá de depurar responsabilidades por lo sucedido, lo sustancial de la misión de Romero perseguía cuatro objetivos: fundar de nuevo la aduana de la Barraca, crear una aduana real en la villa de Sanlúcar, denegar al duque el derecho de hacer franquezas y evitar el cobro de derechos de ondeaje y alcabala en el puerto señorial. A los dos primeros elementos el duque se opuso, alegando que en todo aquel distrito no podía correr más tabla que la de su aduana por privilegio antiguo. Con respecto a los fraudes de la Barraca, don Alonso adujo, además, que sus guardas y sobreguardas, dotados para la vigilancia de una barqueta, se bastaban para controlar un daño que, en todo caso, iba contra su tabla de derechos. Todo ello lo reforzaba con el argumento de que la posesión de la aduana de Sanlúcar era un derecho adquirido por sentencia, "la cual da y pasa a dominio y después de adquirido es de derecho natural y de las gentes". Con respecto a las franquezas, el duque señalaba que no se le podía obligar a no hacerlas él cuando los almojarifes de Sevilla incurrían en la misma falta. Además, dado que los almojarifes presentes en la aduana ducal ya vigilaban el pago de lo acrecentado en todo el distrito de Sanlúcar, no había causa para hacer mayores molestias a los vecinos de su villa. Frente a estos argumentos, las acciones de Romero - que había prendido a ciertos arrendadores de rentas del duque- eran un abuso de su comisión, que en ningún caso le facultaba para tanto. Por fin,

68 La comisión y unas instrucciones tienen fecha de 11 de agosto; la ampliación de la comisión se fechó el 23 de octubre; los autos informando a las autoridades ducales de la comisión son de 10 y 20 de noviembre, todas de 1584. Más tarde, se amplió su comisión a la visita de todas las aduanas del arzobispado de Sevilla y obispado de Cádiz. ADMS, 3.987.

69 ADMS, 3.987, "Memorial de lo que Sevilla [...]". 
Medina Sidonia argumentaba que el ondeaje era consustancial al almojarifazgo que le pertenecía, por lo que era improcedente el intento de perturbarle en su cobro. Más aún, denunciaba que para causarle daño Romero había tratado de retirarle el derecho de percibir la alcabala de lo contratado a bordo de los barcos —es decir, sin desembarcar ni ondear- y en el puerto. ${ }^{70}$

La causa prosiguió con prendimiento de las justicias de una y otra parte y diversas diligencias, ${ }^{71}$ si bien las consecuencias a medio plazo de la visita de Romero se bifurcan en este punto. Por un lado, el proceso judicial sobre el cobro de los derechos acrecentados siguió su tortuoso curso, jalonado de autos y apelaciones, aunque resulta evidente que hacia fines de 1585 se debió alcanzar algún tipo de acuerdo entre el duque y el cabildo de Sevilla. Así, estando en grado de apelación ante el Consejo de Castilla, en palabras de Velázquez Gaztelu, "quedaron estos autos dormidos". ${ }^{72}$ Por otro lado, respecto a las innovaciones institucionales de Romero, tenemos constancia de que las aduanas regias en Sanlúcar y la Barraca se pusieron en funcionamiento, aunque desde muy pronto quedaron la primera marginada y la segunda abandonada.

En efecto, unos años después, finalizado el primer arrendamiento de los dos almojarifazgos de Sevilla por el propio cabildo —entre 1583 y 1592 - , nadie quiso pujar por aquellas rentas en la subasta a la que se procedió. En consecuencia, la Corona hubo de hacerse cargo de su administración hasta 1595, período en el que, contrariamente a lo que en principio pudiéramos pensar, se aprecia cierta subida del valor de los almojarifazgos. ${ }^{73}$ Parte de aquel aprecio de las rentas se debió a la magna visita a todo el comercio andaluz y americano que se encomendó a don Luis Gaitán de Ayala, administrador de los almojarifazgos hispalenses por cuenta del rey y consejero de Hacienda —organismo que se encontraba, a su vez, en pleno proceso de robustecimiento institucional, espoleado por la necesidad de encontrar nuevas fuentes de ingreso- , para tratar de revitalizar dichas rentas. ${ }^{74}$ Fuese culpa exclusiva del cabildo sevillano el descrédito de los almo-

70 ADMS, 3.987, "Memorial de lo que Sevilla [...]".

71 ADMS, 3.987, autos de 4 de febrero y 14 de octubre de 1585 .

72 Velásquez Gaztelu: Historia antigua y moderna..., págs. 94-98.

73 Felipe II felicitó por ello a Gaitán el 11 de julio de 1594. También existe una copia del resumen de su valor desde enero de 1593 hasta junio de 1594. AGS, CJH, 329.

74 La fulgurante carrera de Gaitán había comenzado a descollar con el corregimiento de Madrid, que le valió unos inusuales elogios del Consejo de Castilla en 1592. Fortea, J. I.: "Quis custodit custodes? Los corregidores de Castilla y sus residencias (1558-1658)", en Acta Salmanticensis. Estudios históricos y geográficos, 119 (2003), págs. 179-211, pág. 208. Los cambios en Hacienda en Carlos Morales: El Consejo..., págs. 150-166. 
jarifazgos en aquellos años, como sugiere Lorenzo Sanz, o depreciación de una renta consumida en juros, lo cierto es que la comisión de Gaitán tiene un claro designio de advertencia y corrección de abusos y prácticas fraudulentas. ${ }^{75}$ Es cierto, asimismo, que las dudas generadas por la limpieza de la administración por cuenta del cabildo databan ya de 1584, cuando el Consejo de Hacienda había rechazado la terna de candidatos propuesta por el concejo hispalense para la elección de juez visitador de los puertos por considerar que eran personas "ocupadas y algunas de ellas interesadas y tener deudos con los del cabildo". ${ }^{76}$ Recordemos, además, las denuncias de connivencia entre el cabildo sevillano y el duque de Medina Sidonia expuestas en el memorial de 1585 que analizamos en el apartado anterior.

Sin embargo, hubo dos elementos que hicieron de la visita de Gaitán una fuente inagotable de problemas: la generalidad de su comisión, debida a la gran autoridad que le confería ser al mismo tiempo visitador y administrador de los almojarifazgos; y la circunstancia de que por entonces Felipe II hubiese procedido a introducir una reforma de gran calado en los almojarifazgos de Sevilla, al disponer que en adelante los casos que a estas rentas atañesen serían entendidos por un solo tribunal privativo, el Consejo de Hacienda. Según denunciaba Gaitán, tal medida había generado un fuerte rencor en las instituciones hispalenses, sobre todo en la Audiencia, cuyos miembros desobedecían abiertamente la real orden al tratar de intervenir en su visita, pese a lo explícito de la orden de inhibición. ${ }^{77}$ Según los jueces de la Audiencia, por el contrario, el problema era que Gaitán había hecho de aquella cuestión "punta de honra", llegando a negarse a presentar ante ellos sus poderes. ${ }^{78}$ También el estamento eclesiástico se enfrentó al visitador, quien por su parte lamentaba que los religiosos, so color de llevar mercaderías de su producción y, por tanto, exentas, actuaban como comerciantes intermediarios ${ }^{79}$ En tercer lugar, Gaitán se propuso controlar aquellos lugares que disfrutaban de una gran autonomía. En esta línea, el 11 de enero de 1593 informó al Consejo de Hacienda de su intención de acudir "a reparar los daños que resultan de lo que ha pasado y pasa en Sanlúcar". Allí Gaitán

75 Lorenzo Sanz: Comercio..., vol. II, págs. 399-408.

76 AGS, CJH, 213, c. 1,18 de enero de 1584.

77 AGS, $C J H, 316$, c. 17, 25 de junio de 1593 .

78 AGS, $C J H, 317,25$ de junio de 1593.

79 Una carta de Juan de Salinas al rey — sin fecha—, tratando de una averiguación anterior, acusaba a los vecinos de la villa de Medina Sidonia que cargaban mercancías en Sanlúcar de ser de los que más aprovechaban aquella pretendida exención. AGS, CJH, 226, c. 17. 
siguió la senda abierta por el licenciado Romero, que ya entonces era papel mojado. ${ }^{80}$

Antes de que llegase a Madrid el primer informe de Gaitán sobre lo que sucedía en Sanlúcar, el Consejo de Hacienda ya había recibido un memorial del duque a partir del cual se elevó una consulta al rey sobre la materia. Medina Sidonia se curaba en salud al advertir de las quiebras y daños que se iban a seguir para los almojarifazgos y otras rentas dependientes de ellos si se aplicaban las tablas que en su día había fijado Romero. Resaltaba, por el contrario, la conveniencia que había tenido el acuerdo tomado por él mismo con la ciudad de Sevilla, por lo que suplicaba al rey que no se hiciese novedad en la materia. El duque situaba la cuestión en un plano estrictamente jurisdiccional, al afirmar que sólo perseguía el reconocimiento de la posesión de la aduana heredada de sus antepasados. En cambio, la consulta del Consejo a partir de tal petición entendía de modo muy diferente la labor del licenciado Romero, que estimaba muy apropiada para el buen cobro de la hacienda real. Por eso se pronunciaba a favor de que Gaitán restableciese la tabla de Romero, a pesar del concierto que Sevilla hubiera pactado con el duque. Se oponían igualmente a la sugerencia de Medina Sidonia de buscar un arbitraje, sobre todo si venía de fuera del Consejo de Hacienda, "pues en él se tiene bien entendido lo que esto es y lo que conviene y concuerda hacer en ello". El rey decidió esperar a las noticias del visitador. ${ }^{81}$

El domingo 17 de enero llegó Gaitán a la capital ducal procedente de Lebrija, comenzando inmediatamente su visita, de la que fue dando cumplida cuenta el escribano de su comisión, Hernando de Herrera. Como primera diligencia llamó a los almojarifes de la ciudad para que le informasen del estado de la renta. Al día siguiente, visitó la aduana del duque y, a continuación, la regia, de la cual dijo que estaba mal acomodada — en lugar "alto, pequeño y estrecho"- De este modo, buscó nueva ubicación, encontrando una casa de su gusto frente al mar, en la playa de la ciudad, con comodidad para que se hiciesen llegar allí las mercaderías para ser despachadas y que, además, estaba cerca de la aduana del duque. Mandó aderezar la nueva sede con lo necesario, nombrando almojarifes, receptor de guardas y sobreguardas y arraez de barqueta para dicha aduana y su distrito. El martes acudió a la nueva sede y puso en funcionamiento la aduana, situando a los almojarifes y receptor

80 AGS, CJH, 316, c. 17, 11 de enero de 1593.

81 AGS, CJH, 305, c. 12,19 y 27 de enero de 1593 . 
“con su mesa y libros para el despacho. Y así mismo puso en ella escudos de las armas reales, uno sobre la puerta de la dicha casa y otro en la mesa y asiento de los dichos almojarifes, adonde quedaron despachando los negocios".

A continuación acudió a la venta de la Barraca, donde la aduana regia había sido abandonada. Visto el lugar, Gaitán estimó oportuno que hubiese en ella aduana, repitiendo los actos de jurisdicción, incluida la fijación de la tabla de derechos. Cuando ya se estaban despachando las primeras mercaderías, apareció un ministro del duque, Francisco de Gallegos, procurador y vecino de Sanlúcar, quien contradijo lo realizado, lo cual no impidió a Gaitán proseguir su labor. De vuelta a Sanlúcar, mandó pregonar en tres puntos de la ciudad las aduanas y sus distritos para que los comerciantes se encaminasen a ellas, so pena de descamino. También proveyó un auto que mandó notificar a los oficiales de la aduana ducal en el cual se prohibía de nuevo hacer cualquier gracia o suelta "de los derechos que legítimamente pudieren y debieren llevarles". Para vigilar el cumplimiento de esta disposición, Gaitán dijo tener nombrado un almojarife vecino de Jerez — Martín Ochoa de Olárraga - para que asistiese en la aduana del duque y no consintiese que se hiciesen franquezas, so pena de cobrarlas por el rey "con el cuatro tanto" de penalización, según las disposiciones. ${ }^{82}$

Por otra parte, Gaitán comprobó que el duque seguía cobrando derechos de ondeaje, por lo que el 22 de enero proveyó un nuevo auto para evitarlo. Según su relato, no era legal cobrar esta imposición sobre mercancías que total o parcialmente se encaminase a otros lugares distintos de Sanlúcar, en especial si iban a Sevilla o fuera del reino. Aquella exacción, que Gaitán estimaba muy dañina para el comercio en general, la percibía el duque sumada al almojarifazgo. ${ }^{83} \mathrm{El}$ mismo día, Gaitán informó personalmente al rey en una carta acerca de que coincidía en lo básico con el informe de su escribano, aunque añadía algunas reflexiones muy jugosas. La de mayor enjundia es la que se refería al almojarife de Jerez, Ochoa, a quien puso en la aduana ducal para evitar las rebajas en los derechos. Decía Gaitán que había optado por aquel individuo frente a la oferta que la ciudad de Cádiz le había hecho - que consistía en el envío de un regidor de su cabildo para que ocupase el puesto- porque, si bien la oferta del cabildo gaditano ahorraba el sueldo de Ochoa, la conocida competencia que existía entre Cádiz y Sanlúcar desaconsejaba aceptar "por si se llevaren mal 
los ministros del duque con el de Cádiz". Por otra parte, Gaitán lamentó que el teniente del oficio de escribano de sacas — que lo debía ejercer en nombre de Negrete- " "ni ha servido, ni sirve, ni ha aparecido" en Sanlúcar, porque ello sería motivo de llevar buena contabilidad en las materias de sacas. Por eso se debía compeler a Negrete a que pusiera en ejercicio su oficio. Por lo demás, Gaitán era consciente de que sin la autoridad fuerte de un ministro regio todo lo obrado - tanto en Sanlúcar como en Chipiona, Rota, Lebrija y Cádiz - duraría poco, como demostraba la experiencia, por lo que recomendó al rey que pusiese "alguna persona con jurisdicción" que sustentara lo ejecutado. Haciendo una reflexión más general sobre lo perjudiciales que resultaban para la Real Hacienda "los lugares francos", Gaitán decía no haber querido espiar —-según sus términos- el comercio en Sanlúcar para tomar las mercancías descaminadas por el mucho costo que aquello tendría, prefiriendo consultar a Su Majestad. ${ }^{84}$

En efecto, apenas dos meses de funcionamiento bastaron para demostrar la dificultad de la empresa. En marzo, Gaitán tuvo noticia de que en el almojarifazgo del duque se habían desgajado algunos ramos de cierta importancia - así la madera, jarcias y brea, pescado fresco y salado, frutas secas y carne salada - , de modo que aquellos productos no se despachaban por la vía ordinaria, escapando al control del almojarife regio puesto en la aduana ducal. Para lograrlo, las partidas desgajadas se habían puesto en arriendo o encabezadas en comerciantes que precisamente se ocupaban del ramo, por lo que el fraude era inevitable. Para remediarlo, Gaitán dictó un auto que obligaba a que en adelante se llevase la contabilidad de tales ramos del mismo modo que se hacía con el resto de las partidas del almojarifazgo, en libros registro. Citaba expresamente a todos los ministros ducales para que no cometiesen abusos ni hiciesen gracias. ${ }^{85}$

Por su parte, el duque, que no se había cruzado de brazos ante aquellas novedades tan poco convenientes a sus intereses, estaba ante todo preocupado por el nuevo almojarife real en su aduana, sin cuyo concurso no podrían despachar sus propios almojarifes, según había dispuesto Gaitán. Por eso decidió llevar la negociación al terreno más político que implicaba su apelación directa al rey. Como resultado, una orden de Felipe II al Consejo de Hacienda comunicaba que el duque le había suplicado que no se innovase en la forma en que sus antepasados habían gozado el almojari-

84 AGS, CJH, 316, 22 de enero y 4 de febrero de 1593.

85 AGS, CJH, 316, auto fechado en Sevilla a 23 de marzo de 1593. 
fazgo, para lo cual ofrecía llegar a alguna forma de concierto. El rey preguntó por la oportunidad del acuerdo en términos de justicia y por la consistencia de la alegación ducal, advirtiendo de que la consulta debía discurrir "con mucho secreto", para que

"sin que se entienda que de acá se os ha escrito, os informéis y enteréis de todo y me informéis de ellos [los derechos del duque] en particular y de lo que resultó de las diligencias y autos que en esto hizo el licenciado Romero y el estado en que aquello quedó y el que ahora tiene y podría tener adelante y lo que puede haber importado al duque las sueltas y bajas de derechos que en sus aduanas dicen se han hecho y el perjuicio que de ellos resulta a la renta de mis almojarifazgos y en lo que Cádiz es interesada en ello". ${ }^{86}$

En la respuesta del Consejo se informaba de que el duque solicitaba que todas las novedades hechas por Gaitán - como todas las anteriorescesasen. El Consejo, ante la magnitud del negocio — según reza la consulta, "por ser este negocio de tan grande importancia como es y en que va tanto y que la determinación de él presupone grande deliberación y mucho acuerdo"- se inclinaba por dilatar su respuesta hasta que tuviesen mayor información de lo obrado por Gaitán y de lo alegado por el duque. ${ }^{87}$

Pese a ello, el Consejo no obtuvo respuesta regia de ésta ni de otra consulta de 13 de mayo sobre la misma cuestión. Por eso, en septiembre volvió a consultar al rey, alegando que, pese al silencio, se había vuelto a mirar el asunto de lo "que podría hacerse con el duque", dadas las múltiples instancias que mientras tanto estaba haciendo Medina Sidonia, que habían llevado a que el rey volviese a mandar, por otros conductos institucionales — presumiblemente el Consejo de Castilla-, que se mirase el asunto con celeridad. En todo caso, el de Hacienda se limitaba a posponer de nuevo la respuesta hasta que el nuevo arrendamiento de los almojarifazgos se efectuase, sugiriendo

"que así será bien irlo entreteniendo [al duque] buenamente como pueda hacerse o decirle algo, si sin inconveniente pudiere, por donde entienda que hasta haber arrendado los almojarifazgos no se puede ni ha de tomar resolución en lo que pide".

El rey se conformó, añadiendo que "será bien decirle lo que aquí se apunta y [se] procurará por esta vía que él ayude a lo del arrendamiento y

86 La orden del rey fue despachada al presidente de Hacienda —el licenciado Laguna — por la vía del secretario Gasol. AGS, $C J H, 335$, c. 16, 25 de marzo de 1593 [en el texto se lee 1592].

87 AGS, $C J H, 335$, c. 16,29 de abril de 1593. 
vos, el licenciado Laguna, se lo dad a entender en la forma que fuere mejor". ${ }^{88}$ Desde luego, el celo legalista queda muy reducido en esta respuesta frente a la posibilidad de obtener los fondos que ofrecían, por un lado, un acuerdo con Medina Sidonia y, por otro, la negociación del arrendamiento de los almojarifazgos, negocio en el que se estimaba la ayuda del duque.

Por lo demás, la visita de don Luis Gaitán de Ayala seguía levantando ampollas en todo el entramado del comercio trasatlántico. El propio Gaitán, que, recordemos, era al mismo tiempo administrador real de los almojarifazgos, advertía al Consejo de Hacienda de los excesos que se hacían en la carga de vino y otras provisiones en los barcos de la Guarda de la Carrera, denunciando que el sobrante - lo que no se consumía en el viaje- se vendía en Indias, defraudando a la Real Hacienda. Dichas cargas se hacían en el río de Sevilla — es decir, entre Sanlúcar y la capital hispalense- y los implicados eran, según Gaitán, importantes comerciantes, entre ellos el prior y cónsules. Indicaba que, aunque existía la costumbre de no cobrar derechos en las armadas reales, en la guarda de aquel año bien podría cobrarse, porque su administración la tenía el consulado por el arriendo de la avería. No obstante, Gaitán advertía de que no había hecho nada para impedir tales abusos porque entendía que ya iba muy "cargada" la armada y por no dilatar su salida. De todos modos, había dispuesto la vigilancia en barcazas para controlar más cargazones ilegales. ${ }^{89}$ Tampoco las galeras de España escaparon a su pesquisa, las cuales resultaron acusadas de fraude, hasta el punto de ser señalada esta actividad como la causa principal de que no se hubiesen podido arrendar los almojarifazgos en $1592 .{ }^{90}$

Como hemos visto, al tiempo que avanzaba la pesquisa de Gaitán se estaba negociando el arrendamiento de los almojarifazgos Mayor y de Indias a petición del cabildo de Sevilla, ya desde enero de 1593. ${ }^{11}$ Sin embargo, la discusión de las nuevas condiciones fue compleja, incluso en el seno del propio cabildo hispalense. De este organismo salió una propuesta firme en mayo, según informó el asistente —el conde de Priego- al Consejo de Hacienda. ${ }^{92}$ El rey, en carta a Priego, resumía que, tras haber sido "visto y reformado" el gobierno de los almojarifazgos de Sevilla, ahora el cabildo

88 AGS, $C J H, 335$, c. 16,5 de septiembre de 1593.

89 AGS, $C J H, 316$, c. 17,4 de marzo de 1593.

90 AGS, $C J H, 316$, c. 17,13 de marzo de 1593.

91 Solicitud del cabildo al rey para que una de las personas que acudiesen a negociar el arriendo fuese el Asistente de la ciudad, que era buen conocedor de las cosas de su gobierno. AGS, CJH, 316, c. 17,18 de enero de 1593 .

92 AGS, $C J H, 335$, c. 16,2 de mayo de 1593. 
pretendía tomarlos de nuevo en arriendo por el mismo precio que los había tenido antes. Sin dejar de mostrar su deseo de favorecer a la ciudad, el rey decía que las condiciones que presentaron eran inaceptables, pero dejaba la puerta abierta a la negociación. ${ }^{93}$ A este respecto, el Consejo de Hacienda cifraba el aumento exigible en el precio en diez cuentos de maravedíes, si bien este organismo era más flexible en lo tocante al control de los generales de armadas y galeras, pese a lo delicada que resultaba la materia. ${ }^{94}$

En este contexto, apenas iniciado el debate sobre el arrendamiento, compareció la ciudad de Cádiz por medio de un memorial — dirigido al rey a través del Consejo de Hacienda - cuyo objetivo era de nuevo denunciar los acuerdos entre el duque de Medina Sidonia y el cabildo hispalense. Según este texto, con dichos acuerdos se favorecía sobre todo a Sanlúcar, mientras se dañaba el real patrimonio y a la propia ciudad de Cádiz. Por eso los ediles gaditanos entendían que en aquel arrendamiento se jugaba "la restauración o total ruina de esta ciudad", salvo que el rey mandase que en Sanlúcar se cobrasen por entero los derechos de almojarifazgo y alcabala, como en cualquier puerto regio, evitando los tratos de favor que Medina Sidonia hacía a ciertos comerciantes. Esta era la causa de que el duque interviniese en el asiento del dicho arrendamiento

"so color de decir que Vuestra Majestad se lo ha mandado. Y, como tiene tanta mano en Sevilla, se teme esta ciudad que se asentarán condiciones útiles a la dicha Sanlúcar y en daño de esta plaza".

Para reforzar sus súplicas, destinadas a que nada de aquello se aceptase, el cabildo gaditano acusaba además a Sanlúcar de ser un lugar por el que salía gran cantidad de plata. El rey respondió al memorial afirmando que lo tendría en cuenta en su resolución. ${ }^{95}$

Sin embargo, tras una larga discusión, se dio de nuevo el arrendamiento de ambos almojarifazgos al cabildo de Sevilla por otros diez años, con un aumento de 18 millones de maravedíes con respecto al arriendo de $1583 .{ }^{96}$ Probablemente una intervención de Gaitán, en octubre de 1594, alertando sobre los daños que se iban a derivar a los almojarifazgos si se detenía aquel año la flota en Indias para invernar, figuró entre las causas del repentino desbloqueo de la negociación que trajo consigo la rebaja de las exigencias

93 AGS, $C J H, 335$, c. 16, sin fecha, de 1593.

94 AGS, $C J H, 335$, c. 16,17 de octubre de 1593.

95 AGS, $C J H, 335$, c. 16,28 de noviembre de 1593 .

96 Lorenzo Sanz: Comercio..., vol. II, pág. 405. 
regias, de modo que en diciembre ya sólo el nombramiento de los jueces delegados parecía obstaculizar el acuerdo. ${ }^{97}$ Vista en perspectiva, la comisión de Gaitán tuvo como resultado más inmediato volver a incitar entre ciertos sectores de Sevilla el interés por arrendar los almojarifazgos, incluso a mayor precio, advirtiendo de paso a los interesados del conocimiento que se tenía de sus actividades irregulares. Ante este panorama, la subida del precio alcanzada en 1595, comparada con la ausencia de pujas de 1592, no era poco logro. Que, en todo caso, esta segunda administración de los almojarifazgos por el cabildo hispalense resultase un desastre era algo difícil de prever en los orígenes de la visita de Gaitán. ${ }^{98}$ En todo caso, los efectos a largo plazo de la misión de Gaitán en Sanlúcar fueron, entre otros, la inclusión en la aduana del duque en Sanlúcar de un factor por cuenta del rey, con nombre de almojarife real, aunque sospechosamente su cargo no generó muchos conflictos. ${ }^{99}$ Más sorprendente resulta que, unos años después, un tal Fernando Gaitán de Ayala — acaso hermano de don Luis- estuviese ejerciendo de tesorero de la agencia de Medina Sidonia en Madrid..$^{100}$

\section{Entre el fraude y el contrabando (1600-1618)}

El advenimiento de Felipe III se abrió con unas muy buenas perspectivas para la Casa de Medina Sidonia, entre otras razones porque el duque don Alonso había sabido aproximarse a quien se perfilaba como hombre

97 En febrero de 1594, el mismo Gaitán advirtió que la gestión del conde de Priego había retrasado la negociación, al no haber sabido jugar las bazas regias. AGS, CJH, 335, c. 16, 18 de febrero de 1594 y 329, c. 11, 17 de octubre de 1594; AGS, CJH, 342, c. 10, 12 de diciembre de 1594.

$98 \mathrm{Y}$ ello pese a que, ya antes del traspaso de la administración de estas rentas al cabildo, habían comenzado las irregularidades. El propio Gaitán, antes de abandonar Sevilla, denunció los nombramientos de administradores y jueces a que estaba procediendo el cabildo, que elegía a criados de los veinticuatros. Así, en el reparto de oficios, uno de los más importantes había recaído en el mismísimo duque de Arcos. AGS, CJH, 342, c. 10, 22 de junio de 1595.

99 En 1605, siéndolo aún Martín Ochoa de Ocariz, remitió una carta al secretario Pradera en la que denunciaba que en abril de 1603 Pedro Díaz Picazo, vecino y regidor de Sanlúcar, había comprado en Rota 12 botas de vino de las que no pagó derechos, metiéndolas ocultamente en Sanlúcar, por lo que él las descaminó. Picazo, desacatando de obra y palabra sus órdenes, había ido a Sevilla donde un tal licenciado Hermida — juez de los almojarifazgos — dio mandamiento para que se inhibiese Ochoa. De este modo, Picazo había logrado evitar el castigo, por lo que ahora él suplicaba al rey que diese provisión a Hermida para que concluyese rápido y poder pasar a entender él en la causa. AGS, CJH, 452, sin fecha, de 1605 .

100 Carta del duque al citado en AGS, 2.766, 18 de julio de 1603. Sobre la agencia de Medina Sidonia en la Corte ver Salas Almela L.: "La agencia en Madrid del VIII duque de Medina Sidonia, 1615-1636”, Hispania, 224 (2006), págs. 909-958. 
fuerte del reinado, el duque de Lerma. La ocasión era, por tanto, propicia para poner fin a ciertas disputas antiguas y consolidar sus bases de poder, como puso de manifiesto la compra que el duque don Alonso hizo de la escribanía de las cosas vedadas de la ciudad de Sanlúcar y la Barraca por precio de 4.200 ducados a los pocos meses de la muerte de Felipe II, inversión con la que Medina Sidonia reforzó su control sobre su espacio fiscal. El vendedor del oficio no era otro que el duque de Lerma, quien poseía el oficio por donación real desde hacía pocos meses, y que transformaba así la merced por un lado, en refuerzo de una alianza política y, por otro, en dinero líquido. ${ }^{101}$ De este modo, apenas diez años después de que, tras múltiples pleitos, el oficio se hubiera implantado en Sanlúcar - aunque, como denunciara Gaitán, de forma muy tibia—, su compra permitió a Medina Sidonia neutralizar el peligro que hubiera supuesto para sus propias rentas. Así, el 29 de marzo de 1600 un delegado del duque de Medina Sidonia, el licenciado Jerónimo de Abreu y Soria, tomó posesión quieta y pacífica del cargo, haciendo el gesto ritual de tomar papel y tinta como símbolos de su oficio, cerrando a favor de los Medina Sidonia aquel litigio secular. ${ }^{102}$

Mientras, la administración de los almojarifazgos por parte del concejo de Sevilla seguía su curso entre un clamor de protestas. En 1599, el Consulado de la Universidad de Mercaderes de Sevilla denunció los muchos inconvenientes que aquella administración estaba produciendo en todo el comercio indiano, al tiempo que se postulaba sin disimulo para un próximo arriendo. Los mercaderes aducían no sólo los muchos servicios que hacían a la Corona, sino su gran interés en comerciar de forma legal para garantizar el suministro a los encomenderos y mercaderes en Indias. Esta advertencia, en la coyuntura previa al gran desplome en el volumen de las mercancías registradas con destino a Indias, debe ser interpretada como una forma de llamar la atención sobre cuál empezaba a ser la baza más rentable que se presentaba a los cargadores y a sus proveedores europeos, que no era otra que el comercio al margen del sistema, es decir, el comercio directo y el contrabando. En todo caso, se denunciaba al cabildo hispalense por el excesivo rigor con el que solicitaban las declaraciones juradas a los

101 El título era "escribano de sacas y cosas vedadas, diezmos y aduanas de los puertos de estos reinos y señoríos que hay desde la raya de Portugal [...] y se acaba en la ciudad de Cartagena", de modo que lo que vendía a su consuegro era sólo la parte tocante a Sanlúcar y la Barraca. La causa oficial de la entrega a Lerma había sido el fallecimiento de Jerónimo Negrete y Juan Saravia de Ramales, últimos poseedores. ADMS, 1.022, 28 de diciembre de 1598.

102 ADMS, 1.014. 
cargadores, lo cual estaba produciendo considerables retrasos y que algunos de los más poderosos miembros del Consulado se negasen a cargar. ${ }^{103}$

Evidentemente, la opinión del cabildo era otra. Lamentaban que los del Consulado, "movidos sólo de pasión", se negaran a hacer las declaraciones juradas que eran tan beneficiosas a la Real Hacienda, "pues conocidamente se le encubre tanta cantidad de derechos". Según el cabildo, el motivo que impulsaba al Consulado a querer tomar el arriendo de los almojarifazgos era el de ocultar lo que cargaban, "pues siendo ellos los que han de adeudar los derechos y cobrarlos no podrá haber quien los castigue y descubra sus fraudes". Apelaban a la real conciencia para que no consintiese que el Consejo de Hacienda entrase en la plática sobre hacer un nuevo contrato de arriendo porque, además de estar estipulado en las condiciones firmadas en 1595 con el cabildo que no se haría tal cosa hasta finalizado el arriendo, no había razones para ello. Asimismo vaticinaban que, de arrendarse al Consulado, se cerraría el comercio a quienes no estuviesen integrados en él. Frente a este peligro, el cabildo afirmaba que había procedido "haciendo franquezas y dando todo buen despacho, con lo cual ha animado a que con más gana traten y las rentas y alcabalas de Vuestra Majestad se aumenten, y disimulando el dicho cumplimiento de dichas condiciones por el servicio e interés de Vuestra Majestad". Es decir, que habían renunciado a parte de los derechos adquiridos por animar la contratación. Por último, esbozaba el cabildo el argumento de que siendo el Consulado una congregación, nadie quedaría obligado en caso de quiebras. ${ }^{104}$ En nuestra opinión, lo que esto implica son dos formas opuestas de afrontar la supervivencia del comercio americano de Sevilla. Por un lado, el Consulado proponía evitar la tentación del contrabando, permitiendo un amplio margen de fraude, con la garantía de hacer frente a los pagos acordados con la Corona en el arriendo. Por otro, el cabildo pugnaba por no ser excluido de la gestión del comercio, blandiendo el argumento de que la inspección fiscal siempre sería más rentable para las arcas del rey. En ambos casos, el peor escenario previsible era la ausencia de mercaderes en los puertos, lo que ni más ni menos significaba comercio directo.

De todos modos, pese al alegato del cabildo, ante el cúmulo de quejas y las muchas quiebras en el pago de juros, en 1602 se suspendió su arrendamiento de los almojarifazgos. En su lugar, el capitán Juan González

103 AGS, CJH, 388, c.13, 18 de septiembre de 1599.

104 AGS, CJH, 432, 1 de enero de 1602. 
de Guzmán logró convencer al rey, a Lerma y a don Rodrigo Calderón — según él mismo relató más adelante- de la bondad de su oferta para mejorar dichas rentas y alzarse con el arrendamiento, pese a la oposición del Consulado. ${ }^{105}$ Parte sustancial de la capacidad de persuasión de González de Guzmán se debió a que pujó un aumento de 95 cuentos y medio del valor de los almojarifazgos. Sin embargo, como él mismo lamentó, el Consejo de Hacienda primero le negó los prometidos, más tarde no tuvo en cuenta las bajas en el comercio y, por último, permitió cargar sin hacer las declaraciones juradas, lo cual contradecía su contrato con la Corona. Peor aún, tras haber empezado, pese a todo, a pagar en mayo los juros cargados sobre los almojarifazgos, poco después se publicó el llamado decreto Gauna "con que incontinenti cesó el comercio y cesaron de venir las naos que estaban en Calais y en Alemania". ${ }^{106}$ En tales condiciones, al haber dejado González Guzmán de pagar los juros, el Consejo de Hacienda envió dos superintendentes que comenzaron a tomarle cuentas con todo rigor, como si hubiera acabado su administración. Con tales agravios, González de Guzmán pidió que se le hiciese justicia o se le dejase abandonar el almojarifazgo, solicitando también amparo al duque de Medina Sidonia. El duque, por su parte, se dirigió al presidente de Hacienda recomendando que se mantuviese a González de Guzmán en su crédito, aunque reconocía en carta a Calderón que la quiebra total era posible. ${ }^{107}$ En todo caso, el arriendo no duró mucho y ya a finales de 1603 fueron los superintendentes - Bernabé de Pedroso, del Consejo de Castilla, y Alonso de Espinosa, de Hacienda - quienes tomaron la administración por cuenta regia. ${ }^{108}$

En su petición de amparo al duque, González de Guzmán había señalado varios asuntos de gran trascendencia que por entonces estaban centrando las tensiones en torno al comercio americano. La que aquí más nos incumbe es el espinoso asunto de las declaraciones juradas de lo embarca-

105 Consulta del Consejo de Estado sobre las críticas del Consulado a González de Guzmán en AGS, Guerra Antigua, 3.916, 12 de agosto de 1603.

106 Sobre el decreto Gauna ver Girard, A.: Le commerce Françoise à Seville et Cadix aux temps des Habsbourg: contribution à l'étude du commerce étranger en Espagne aux XVI et XVII siècles, Féret \& Fils, París, 1932, págs. 55-56; Stradling, R. A.: La arma de Flandes. Política naval española y guerra europea, 1568-1668, Cátedra, Madrid, 1992, págs. 36-37; Gelabert, J. E.: La bolsa del rey. Rey, reino y fisco en Castilla (1598-1648), Crítica, Barcelona, 1997, pág. 20.

107 AGS, $C J H, 432,30$ de septiembre, 6 de octubre (2) y sin fecha, de 1603

108 No sabemos si González de Guzmán llegó a ser encarcelado, aunque sí que Medina Sidonia medió, sin implicarse en exceso, para evitarle aquel castigo. AGS, CJH, 446, 1 de enero de 1604. 
do, que tanto rechazo generaban en los comerciantes. Aquella cláusula, apoyada desde el Consejo de Hacienda, era rechazada por la Casa de la Contratación y sobre todo por el Consulado. Mientras las instituciones comerciales hispalenses seguían defendiendo una forma de pacto de compensaciones mutuas que no excluía sustanciosos beneficios para los mercaderes y cargadores, el Consejo de Hacienda se situó como adalid de la legalidad, enarbolando el estandarte del mayor beneficio fiscal de la Corona y denunciando las prácticas contrarias. Esta tensión se plasmó en 1604, cuando, estando en Sanlúcar el alcalde Portocarrero - encargado por la Casa de la Contratación del despacho de las flotas-, se encontró con que la flota de Nueva España, lista para emprender viaje, se veía ahora en peligro de no zarpar por los intentos de Bernabé de Pedroso de obligar a hacer relaciones juradas a los cargadores. Vista la situación y para agilizar la partida de la armada, el Consejo de Hacienda consideró útil suspender excepcionalmente aquella obligación a cambio de que se hiciesen estimaciones someras. Sin embargo, la publicación del cese de la obligación del juramento produjo un considerable alboroto en Sevilla, Cádiz y Sanlúcar. La causa, según denunció el Consejo de Hacienda, era que al tener noticia de que no se pedirían declaraciones, la Casa de la Contratación lo publicó por pregón, dando lugar a una avalancha de embarques de última hora, cuyos mayores beneficiados eran

\footnotetext{
"los cargadores de los dichos presidente, jueces y oficiales, y que podría ser que entre otros fraudes intentasen, no contentándose con no dar las dichas relaciones juradas [...] de darlas a tiempo que con seguridad las puedan dar faltas y diminutas de la verdad en cantidad y precios de las mercadurías que cargaren".
}

Aquello no venía a ser, según el Consejo, sino un episodio más de la continuada y antigua tendencia del comercio sevillano a tratar de defraudar los derechos reales. ${ }^{109}$

En estas circunstancias, a fines de 1604, se firmó con Pedro Gómez Reynel un nuevo arriendo de los almojarifazgos sevillanos. ${ }^{110}$ También breve y poco exitoso, el arriendo de Reynel parece que venía lastrado desde el principio por las condiciones pactadas. Una de ellas contemplaba la prohibición de cargar mercancías para Indias fuera de los puertos de Sevilla y Cádiz "y no en otra parte, so pena de perderlas", condición que se espe-

109 AGS, CJH, 441, la carta de Portocarrero de 26 de abril de 1604, el resto sin fecha.

110 Gelabert: La bolsa..., pág. 129. 
raba minase el fraude cometido bajo el amparo de la jurisdicción militar. Ateniéndose a esta condición, el licenciado Diego de Landeras Velasco, juez de la Audiencia y conservador de los almojarifazgos de Sevilla, denunció en 1605 que por entonces Juan Núñez Correa — que era desde 1603 asentista para la provisión y apresto de la Armada de las Indias- ${ }^{111}$ pretendiese cargar lo necesario para el despacho de los galeones en Sanlúcar y otros lugares, contando para ello con el amparo del alcalde Martín Fernández Portocarrero - a la sazón juez único de las causas civiles y criminales que tocaban al oficio de Correa, jurisdicción que pretendía ejercer incluso si se trataba de causas contra el asiento de Reynel- ${ }^{112}$ Landeras advertía que, de permitírsele cargar, se producirían gran cantidad de fraudes, ya que el propio Núñez Correa y sus deudos embarcarían mercaderías sin control alguno. El Consejo opinó que se debía respetar la exclusividad de Sevilla y Cádiz para evitar los abusos que se cometían en los aprestos militares, como "dicen suele suceder". La consulta iba más allá, al señalar que lo peor no era el fraude, sino que los barcos de guerra dejasen de llevar los bastimentos militares necesarios hacer sitio a las mercaderías. A tanto llegaba el abuso que, en opinión del Consejo, nadie quería cargar por la vía legal, al no poder competir en Indias por ir muy gravadas las mercancías. Más concreta era la preocupación de Núñez Correa ante la posibilidad de tener que llevar de nuevo a Sanlúcar las mercancías para el abasto de las flotas que él mismo había comprado en Jerez, dado que sería a su costa. El Consejo propuso la solución de mandar que se guardase lo dispuesto anteriormente, es decir, que Portocarreo se encargase de dar cédula, señalando qué cosas debían ir en cada barco, mientras las cédulas serían presentadas en Sevilla ante Correa para su aprobación y despacho. ${ }^{113}$

A mediados de 1606, Gómez Reynel fue encarcelado, mientras la gestión de los almojarifazgos quedaba en manos de Domingo Zabala — del Consejo y Contaduría Mayor de Hacienda-, especialmente comisionado

111 Núñez Correa había firmado su asiento con Felipe III para la administración de la avería, al mismo tiempo que lo hiciera Núñez de Guzmán con el arrendamiento de los almojarifazgos. Se preveía una bajada de los derechos pagados por el comercio del 2 al $1 \%$ de ida y se mantenía de momento en el 6\% de vuelta, mientras se cumplía con las quiebras pasadas. AGS, Guerra Antigua, 3.916, 8 de julio de 1603 .

112 Al fin, la quiebra del contrato de arriendo de Pedro Gómez Reynel, que arrastró la amenaza en el pago de juros en dos años consecutivos, llegó a amenazar el orden público en Sevilla. AGS, CJH, 474, carpeta 13, passim.

113 AGS, $C J H, 457,14$ de febrero de 1605. 
para ello ${ }^{114}$. En ese contexto de interinidad, en 1607 volvió a denunciarse que en Sanlúcar se cobraban derechos de ondeaje. El juez entonces remitido -el alcalde Núñez Morquecho- encontró los consabidos problemas e incomodidades en sus averiguaciones en la capital ducal. Según confesaba en carta al secretario Contreras, "en mi vida tuve comisión de más disgusto $[\ldots]$ porque aunque el duque no entra ni sale en él, como tengo presos a sus criados $[\ldots]$ paso muchas pesadumbres". Tras las primeras averiguaciones, el Consejo de Hacienda ordenó cobrar del receptor de la aduana del duque la cantidad que hubiera percibido en concepto de ondeaje, al tiempo que se pregonaba en Sanlúcar y Sevilla que no se cobraría más. En cuanto a las actuaciones contra los criados del duque — para las que Morquecho contó con el asesoramiento del propio Zabala-, se iniciaron contra los receptores de derechos ducales, ya que Bartolomé Juárez — almojarife del duque- logró eludir las comparecencias. Incluso los receptores ducales lograron huir a Sevilla, donde hicieron "grandes diligencias" en diversas instancias de justicia. En tales condiciones Núñez Morquecho suplicaba

\footnotetext{
"se me envíe provisión con inhibición y que tampoco conozcan [en la Audiencia] por vía de hecho, porque no obstante que mi comisión dice que cobre la dicha cantidad de los receptores y de otra cualquier persona a cuyo cargo es y ha sido la paga, estoy temeroso que me han de dejar frustrada la ejecución de la dicha provisión".
}

El alcalde insinuaba con claridad que detrás de todo aquello estaba la mucha mano que el duque tenía en la Audiencia. De hecho, la aceptación de la causa en Sevilla ya significaba, según lamentaba Núñez Morquecho, una forma de desacato a su comisión y una ralentización en los autos, sobre todo porque así quedaba desautorizado el ejecutor que él había nombrado en Sanlúcar. ${ }^{115}$ Como se ve, la gama de posibilidades que tenía Medina Sidonia de evitar la aplicación de medidas poco gratas a sus intereses era enorme, tanto que, tras casi 40 años de reinado del duque don Alonso, la Corona se mostraba incapaz de atajar el cobro del ondeaje.

Ya en 1609, justo cuando la Tregua de los Doce Años abría un margen de esperanza para la reactivación del comercio, don Alonso llegó también a un acuerdo o concordia con la Corona sobre la aduana, firmada con Domingo de Zabala, todavía administrador general de los almojarifazgos Mayor y de Indias de Sevilla. Se trataba de un acuerdo sobre los descaminos

114 Gelabert: La bolsa..., págs. 129-130.

115 AGS, CJH, 480, c. 22, 16 (2), 17 y 23 de octubre de 1607. 
por fraude contra los derechos de la aduana del duque, que dejaba aparte aquellos que en exclusiva competían a la aduana real, como era todo lo tocante al comercio con Indias. El preámbulo del acuerdo aludía a las discordias constantes que se producían entre los ministros de las aduanas del rey y de Medina Sidonia en Sanlúcar por causas de jurisdicción, ya que unos y otros trataban de llevar las causas a sus aduanas. Según denunciaba el acuerdo, esto originaba la pérdida de no pocas causas o que se viesen sin el cuidado oportuno, porque los jueces llegaban a composiciones con los acusados en daño de la Hacienda real. Se advertía asimismo de la importancia que tenía la asistencia de los ministros a las condenaciones, porque si no concurriesen los jueces de una aduana al reparto, quedaba todo el tercio correspondiente para los que sí hubiesen asistido. El punto esencial, en todo caso, era la fijación del gravamen en los supuestos de entrada y salida de mercancías. ${ }^{116}$ Con respecto a lo descaminado en Sevilla, en el condado, en Cádiz o en otras partes tampoco competían a este acuerdo por no deberse allí derechos a la aduana del duque. Al fin, el texto ordenaba a los almojarifes y oficiales de la aduana real que cumpliesen estos términos, aunque reservaba el derecho regio a alterar las condiciones sin que el duque pudiera apelar al acuerdo. ${ }^{117}$ Hay que señalar que entre los motivos inmediatos que facilitaron aquel reparto de competencias en materia de descaminos, figura sin duda el litigio que había enfrentado a las justicias regias con las ducales por la posesión de un oficio sobre el comercio: la alcaldía mayor de sacas. ${ }^{118}$

116 Disponía que en adelante se repartiese del siguiente modo: primero, "que las cosas que se descaminen de entrada por la mar, cuyos derechos tocan a la aduana del señor duque, lleve Su Excelencia toda la condenación y nada el aduana del rey, porque no se le deben derechos de entrada". En segundo lugar, si las cosas descaminadas que hubiesen entrado por mar fuesen vedadas — cuyos derechos tocaban a la aduana real—, se debía partir la condenación entre el rey y el señor duque, haciendo un prorrateo de la cantidad que tocaba a cada uno conforme a los derechos que tenían señalados en la ciudad, es decir, en función de las tablas. En tercer lugar, las cosas descaminadas que fuesen de entrada por tierra en Sanlúcar y no viniesen despachadas de una aduana real, se partiría asimismo la condenación a partes iguales, pero si venían despachadas de una aduana real correspondería todo al duque. Cuarto, lo que se descaminase de mercancías de salida por tierra se repartiría igualmente entra las dichas dos aduanas. Quinto, en las cosas descaminadas de salida por mar — que no pagaban los mismos derechos, sino que unas pertenecían al rey al 7' $5 \%$ y otras al 5\%, mientras corrían al 2'5\% las que pertenecían al duque - se debía hacer cómputo global del monto, repartiendo en función de estos mismos derechos. Incidía en que aquello se refería al reparto del tercio de los jueces es decir, el tercio de los guardas, jueces y escribanos que asistiesen al descamino — siendo los otros dos tercios uno para la aduana y otro para el denunciador-.

117 ADMS, 1.014, 18 de marzo de 1609.

118 Aunque en 1596 Medina Sidonia pudo demostrar que había comprado el oficio, Felipe II lo volvió a incorporar a la Corona, compensándole por el desembolso. ADMS, 1.021, información de 12 de noviembre de 1596; Ibídem, 996, sentencias de 30 de mayo de 1609 y 15 de octubre de 1611. 
Por su parte, en las circunstancias marcadas por este nuevo acuerdo, el duque don Alonso modificó de forma significativa la orientación de sus aspiraciones. En 1610, ante la alarma causada por el aumento del contrabando de moneda falsa de vellón introducida en Castilla, Medina Sidonia remitió una consulta al Consejo de Estado - del cual era miembro- proponiendo ciertas reformas para atajar el problema. Ante todo indicaba que era preciso que la inspección de los buques se hiciese en Sanlúcar, donde recordaba que él ya no cobraba ningún derecho por ese motivo. De otra forma no tendría remedio, porque en las 12 leguas de despoblado que había en el recorrido del río entre Sanlúcar y Coria los barcos desembarcaban cuanto querían de moneda falsa y mercaderías, sobre todo porque contaban con "valedores" en tierra. Decía don Alonso que eran "materias en que no se puede hablar, aunque piden harto remedio". De este modo, visitar los buques antes de que pasasen a Sevilla era la forma de asegurar la persecución de aquel comercio, para lo que el rey podía contar con "el rigor que allí [en Sanlúcar] se tiene en el cumplimiento de las órdenes por estar el duque presente". La respuesta del Consejo y del rey fue dar competencia al duque para averiguar lo que insinuaba. ${ }^{119}$ Desde el punto de vista de Medina Sidonia, este intento parece indicar que, ya que no podía cobrar ciertos derechos, al menos esperaba extender su jurisdicción en la persecución del fraude. De este modo, aseguraba para sí cierto protagonismo en el área, haciendo pesar la amenaza implícita de que en su mano estaba abrir o cerrar aquella sangría.

En todo caso, en los años siguientes se detecta una menor tensión entre las aduanas regia y ducal, en parte motivada por la coyuntura de relativo crecimiento del comercio con Europa que se había experimentado desde la firma de la Tregua con las Provincias Unidas. ${ }^{120}$ Sin embargo, ni estas circunstancias ni el acuerdo de 1609 entre el duque y la Corona pusieron fin a las esporádicas "vejaciones" de las que se lamentaba un corregidor sanluqueño, padecidas sobre todo por extranjeros afincados en la ciudad. ${ }^{121}$ En uno de estos roces, en 1616, el licenciado don Juan de Liébana, miembro del Consejo del duque y corregidor de Sanlúcar, expuso pormenorizadamente el tipo de abusos cometidos por los guardas mayores y menores

119 AGS, Estado, 2.640, d. 81, 14 de agosto de 1610.

120 Israel, J.: La República holandesa y el mundo hispánico (1606-1661), Nerea, Madrid, 1997 [1982], págs. 58-59.

121 AMDS, 1.022, auto de 13 de junio de 1615. De nuevo el implicado era un delegado de Jerónimo Guardiola. 
remitidos desde Sevilla. En primer lugar, daba a entender que los guardas no presentaban oficialmente su cargo a las autoridades locales, sino que la noticia de su presencia en Bonanza la recibían los ministros del duque a través de las denuncias de los mercaderes extranjeros, que se lamentaban del modo indigno en que eran registrados, afirmando que en la playa "las dichas guardas los desnudan para mirar lo que llevan, causando mucho escándalo". ${ }^{122}$ Todo ello, además, contravenía las disposiciones reales dictadas con el fin de promover el buen trato a los extranjeros y suponía, en su opinión, una usurpación de su jurisdicción ordinaria. ${ }^{123}$ Sea como fuere, cuando aquellos problemas de competencias tenían cierta enjundia, rápidamente derivaban hacia instancias más altas. Así, frente a los autos del corregidor señorial los subdelegados del alcalde de sacas pidieron el amparo del Consejo de Hacienda. ${ }^{124}$ No obstante, cuanto más alta era la instancia, más fácil era que Medina Sidonia negociase en términos políticos, campo en el que tenía mucho más que ganar. Por ejemplo, en 1618 Felipe III revocó la autoridad a los delegados del juez de sacas para la fiscalización de los extranjeros, concediéndosela expresamente a Medina Sidonia. ${ }^{125}$ De hecho, hasta 1634 no fue recibido por el cabildo de Sanlúcar ningún alcalde de sacas por cuenta del alcalde mayor de este oficio en Sevilla. ${ }^{126}$

\section{Donativos y tolerancia (1618-1641)}

Tal vez porque el efecto combinado del acuerdo de 1609 sobre la aduana de Sanlúcar y la rectificación del oficio de juez de sacas de 1618 diese lugar a un cierto equilibrio jurisdiccional, las disputas específicas entre las aduanas regia y ducal disminuyeron aún más de intensidad y calado en las dos décadas siguientes. Tampoco está de más recordar que en los comienzos del reinado de Felipe IV se aceleró el desplome en los registros de la Casa de la Contratación, que la historiografía relaciona con el aumento paralelo del fraude, dando lugar a un sistema de tolerancia a cam-

122 ADMS, 1.022, auto de 25 de enero de 1616.

123 Para ello, como primera providencia, a la espera del dictamen de Hidalgo ordenaba suspender el oficio de los guardas. ADMS, leg. 1.022, 25 de enero de 1616.

124 ADMS, leg. 1.022, solicitud de amparo de Lázaro Sanz.

125 No hemos encontrado más que una referencia de archivo del siglo XVIII a esta concesión. Se cita la fecha del documento a 21 de junio de 1618. En ADMS, 1.022.

126 Velásquez Gaztelu: Historia antigua..., pág. 345. 
bio de donativos y servicios extraordinarios pactados en momentos de apuro, política que aspiraba a volver a atraer mercaderes a Andalucía. En este sentido, la amplia colaboración que el duque don Manuel Alonso - que reinó entre 1615 y 1636- prestó al régimen de Olivares, sobre todo en la década de 1620, pudo ser el equivalente sanluqueño a los servicios concedidos por el Consulado y el comercio de Sevilla a cambio de un cierto dejar hacer. Sin embargo, sería inexacto afirmar que el conflicto desapareció en aquellos años. Por el contrario, lo que hizo fue desplazarse a un plano más general, como es el que suponía la guerra comercial contra los holandeses, reemprendida con decisión por Felipe IV, ${ }^{127}$ materia que abordamos en otro lugar.

Tras el desastre de Matanzas, sin embargo, y en el contexto de los primeros grandes reveses del reinado, las tensiones por hacer rendir más las fuentes de ingresos volvieron a generalizarse. Como bien ilustra el llamado "descamino grande de plata" de 1633 — que no salpicó directamente al duque de Medina Sidonia, aunque sí a sus vasallos-, a aquellas alturas nadie se llamaba a engaño sobre la extensión del fraude en todo el entramado comercial del bajo Guadalquivir, Cádiz incluida. Aquel año se descubrió en una de las flotas de Indias una enorme cantidad de plata embarcada sin registro y cuyos destinatarios últimos eran mercaderes franceses. Según el licenciado Paz de Cuellar, en una carta a Felipe IV, lo que había causado mayor escándalo en aquel caso era la nacionalidad de los beneficiados, lo cual había impedido practicar la tolerancia de casos anteriores en los que los destinatarios eran súbditos del Rey Católico. Don Juan de Santaelices — regente de la Audiencia - fue más allá al señalar que en aquel caso estaba implicada la mayor parte del comercio de Sevilla y Sanlúcar. El regente propuso dos medios para actuar: uno duro, en el que saldrían culpados todos los comerciantes mayores y medianos de ambas ciudades, con gran escándalo y mucha dificultad de cobro por la naturaleza de las haciendas de estos comerciantes, muy protegidas ante cualquier ejecución judicial; por otro lado, el blando, que se basaría en la búsqueda de un acuerdo para que entre los comerciantes se extrajese un gran donativo o, en su defecto, lograr que, a cambio de la amnistía, se hiciesen cargo de la avería. En todo caso, para dar apariencia de severidad, debía darse un ejemplo público sobre las espaldas de algún implicado de menor fortuna. ${ }^{128}$

127 Israel: La República holandesa..., págs. 109-142.

128 AHN, Consejos, 7.227, f. 8r-14v, 16 y 23 (2) de agosto de 1633. 
De todos modos, la extensión de la pesquisa aquel año debía mucho a la disputa entre las diversas jurisdicciones, es decir, al deseo de dañar la jurisdicción del otro. Así, si la investigación arrancó con las pesquisas ordinarias de un juez de sacas - don Francisco de Vargas-, la presencia en Sevilla de un juez conservador del Consejo de Hacienda — don Luis de Baeza y Mendoza - produjo el deseo de profundizar en la averiguación de lo sucedido, sin que se encontrase el freno habitual que suponía el soborno. Por su parte, el conde de Peñaflor — presidente de la Casa de la Contratación-, trató de abocar sobre sí toda la causa de la plata venida fuera de registro. Así, fue el azar de la colisión de tres jurisdicciones - las de Indias, Hacienda y Castilla - lo que destapó el escándalo.

A Sanlúcar fue remitido el licenciado Quiroga, cuyos desvelos por tratar de averiguar las cuentas de los comerciantes de la ciudad fueron infructuosos en su mayor parte. En la correspondencia con sus superiores, Quiroga acusaba al duque de que, aunque no iba a impedirle seguir sus diligencias, todo aquello le dolía como cosa propia. ${ }^{129}$ Pese a la opinión contraria del Consejo Real, ya en septiembre, el rey mostró su intención de componer un perdón general a cambio de 100.000 pesos, del cual sólo excluyó a los oficiales de la Armada que hubiesen resultado culpados. El alto tribunal entendía que sólo se debía aceptar la composición en materia de fraude - la venida de plata fuera de registro-, pero bajo ningún concepto se debía admitir tal plática en materia de sacas, sobre todo si iba dirigida a enemigos, porque ellos se enriquecían a costa de empobrecer al reino. Así, aunque se dañase algo el comercio, el Consejo opinaba que se debía aplicar el castigo sobre las causas de sacas con todo rigor, dando por supuesto que los principales culpados serían extranjeros. ${ }^{130} \mathrm{Al}$ fin, a principios del año siguiente se llegó a una composición con el Consulado por un valor de 200.000 ducados. ${ }^{131}$ Pero el torrente del fraude era incontrolable: apenas dos meses después, en marzo de 1634, a la llegada de la flota de Tierra Firme bajo el mando del marqués de Cadereyta, la diferencia del monto de la plata que se declaró en Sevilla - tres millones de pesos- con respecto a lo embarcado en América - ocho millones- dejaba en evidencia la magnitud, extensión y variedad que había alcanzado el fenómeno. En este caso, el sistema utilizado había sido el desembarco de los metales pre-

129 AHN, Consejos, 7.227, f. 16r-19v, 22 de agosto de 1633.

130 AHN, Consejos, 7.227, f. 16r-25v, 22 de agosto, 1 y 6 de septiembre de 1633.

131 AGS, $C J H, 717,1-18,4$ de enero de 1634. 
ciosos en pequeños barcos por toda la costa andaluza antes de la entrada en Sanlúcar, haciendo inútiles todas las prevenciones, guardas y vigilancias. ${ }^{132}$

Medina Sidonia, por su parte, no pudo mantenerse al margen, sino que fue también objeto de una acusación muy grave formulada por un consejero de Estado, don Carlos Coloma - con el apoyo del conde de Villahermosa. Coloma, que llevaba años denunciando la mucha plata que se sacaba por los puertos andaluces, recordó —en una reunión monográfica del Consejo sobre el comercio en Andalucía- que, siendo embajador en Inglaterra, había denunciado la saca de moneda que se producía, según él, sobre todo en Sanlúcar y además "por conveniencia de los mismos a cuyo cargo estaba el defenderla". Estimaba muy necesario adoptar medidas extraordinarias para afrontar un problema que consideraba esencial y cuya solución no podía pasar sólo por poner personas "de buena vida". De momento, proponía la formación de una Junta especial para estudiar las medidas. Frente a aquella opinión, el marqués de Santa Cruz y el conde de Castrillo opinaron que la mejor solución pasaba por procurar quitar incentivos a la carga fuera de registro, lo que implicaba moderar los derechos que se cobraban. El conde de la Puebla, por su parte, incidió en los problemas diversos que causaban el contrabando y el fraude, extendiendo su acusación a todos los ministros en general que se ocupaban del asunto. El rey se conformó con Castrillo y la Puebla, lamentando que "no hay justicia ni se hace en estas materias de codicia". ${ }^{133}$

En estas circunstancias, estando tan cuestionado el comercio de Sanlúcar, poco pudo oponer el duque a la petición que en 1637 recibió del rey para colaborar con don Bartolomé Morquecho en la composición de un donativo que se debía sacar de Sanlúcar, Sevilla, Jerez y El Puerto de Santa María. El monto venía prefijado en 800.000 ducados y la causa formal era el consabido alivio de las deudas regias con los hombres de negocios y asentistas. Nótese que la tasación previa de lo donado transformaba la misión de Morquecho más bien en la ejecución de una derrama forzosa, ${ }^{134}$ si bien para su cobro se procedería a la imposición de una sisa sobre el volumen de lo negociado en las aduanas de toda la región. Morquecho, que obtuvo un 1’25\% de imposición en los demás lugares, no logró sacar del duque para cobrar en Sanlúcar más que un 0'5\%, por lo que el rey le instó a aumentarlo al menos al $1 \%$ que ya había ofrecido Sevilla. El rey, aunque

132 AGS, $C J H, 714,1-11,3$ de marzo de 1634.

133 AGS, Estado, 2.657, 3 de junio de 1636.

134 AHN, Consejos, 13.199, exp. 53, 20 de julio de 1640. 
agradeció al duque que, como dueño de la aduana, hubiese consentido la nueva imposición, no dejó de recordarle que hacer tales actos fiscales era parte de su regalía, de modo que pedir su mediación debía ser entendido sólo como una deferencia para facilitar el logro y no como un derecho. ${ }^{135}$

\section{Conclusión}

En los años de los que se ocupa este trabajo, los Medina Sidonia sostuvieron con notable éxito su empeño por mantener bajo su control un espacio fiscal propio en un área de gran trasiego comercial y, por virtud del cual, Sanlúcar tuvo un cierto peso en la evolución del sistema comercial castellano. Ahora bien, las peculiaridades que otorgaba a esta ciudad su condición de puerto señorial, hicieron que las tensiones a que se vio sometida y las soluciones que se arbitraron presenten concomitancias y diferencias con los otros agentes implicados. Buena parte de la capacidad mostrada por los Medina Sidonia en la salvaguarda de sus privilegios se debió a la complejidad de intereses que se concitaban en torno al gran comercio internacional, tanto en Sevilla como en la Corte, de modo que los duques pudieron maniobrar con un amplio margen entre instituciones y personas, incluidos monarcas y validos.

En la primera etapa, los Medina Sidonia defendieron sobre todo judicialmente la prevalencia de su derecho frente a las reformas legislativas que la Corona trataba de imponer para hacer rendir más sus fuentes de ingreso. En este sentido, lo más significativo de los argumentos ducales es su apuesta por defender un marco jurídico determinado en el que los derechos señoriales no tenían por qué ser marginados por las iniciativas regias. Sin embargo, la férrea voluntad de la Corona aconsejó acompañar la batalla jurídica con otras formas de ganarse el favor regio, como era la activa participación en la defensa costera, plasmada en la Capitanía General. Este doble impulso, unido a su autoridad y poder de facto, permitió a los Medina Sidonia conservar sin apenas interferencias externas la gestión de su espacio fiscal hasta los inicios del siglo XVII.

135 AGI, Indiferente, 434, lib. 8, 220r-240v, 4 de febrero, 18 y 26 (4) de mayo, 12 y 14 de junio y 18 de agosto (3) de 1637. Ver también Salas Almela, L.: Colaboración y conflicto. La capitanía general del Mar Océano y Costas de Andalucía, 1588-1660, Universidad de Córdoba, Córdoba, 2002, págs. 150-151. 
Ahora bien, el desplome del edificio fiscal que la Corona había construido sobre la Carrera de Indias se produjo, a pesar de que la Monarquía se iba adueñando de la exclusividad del concepto de fraude fiscal, pasando así en el terreno doctrinal a situar su regalía por encima de cualquier otra fuente de derecho, incluida la tradición. Esta situación situaba, a su vez, a los Medina Sidonia en una posición más emparentada con los impulsos que guiaban al Consulado de Sevilla que con los esfuerzos de la Corona por mantener una ficción legal cuyo control se les escapaba. Así, la aparición hacia 1600 de la cobranza de los mercaderes bretones como principal ingreso de la aduana ducal cabe ser interpretada como la contrapartida que los mercaderes extranjeros pagaban al duque por obtener una protección que pasaba por fiscalizar de modo muy somero sus operaciones. A cambio, de forma similar a como los comerciantes agrupados en el Consulado compensaban a la Corona por sus conocidas irregularidades, los Medina Sidonia no dejaron de mostrarse solidarios con el nuevo reinado y generosos con los donativos que les fueron pedidos o exigidos durante el valimiento de Olivares. A la postre, este nivel de acuerdo demostró ser muy vulnerable a las coyunturas políticas cuando en 1641 todo el edificio legitimador construido entorno a la fidelidad a la Monarquía de los Pérez de Guzmán se vino abajo al ser acusado el IX duque, don Gaspar Alonso Pérez de Guzmán, de conspiración contra Felipe IV.

Por tanto, sostenemos que Sanlúcar no fue sólo el antepuerto de Sevilla: la sede de la corte ducal de los Medina Sidonia era una pieza fundamental con la que los reyes castellanos hubieron de contar para que cualquier medida de control fiscal sobre el comercio indiano se aplicase con eficacia. O, dicho de otro modo, sin la colaboración activa de los Medina Sidonia, Sanlúcar suponía un escollo potencial difícil de superar para las políticas regias. Visto de este modo, podemos afirmar que los duques mantuvieron una mesura en la defensa de sus intereses que les permitió evitar el conflicto abierto con la Monarquía por esta causa. Los roces y las disputas - cuya aspereza se percibe casi siempre en el nivel local— no deben ocultar el hecho de que sobre la boca del Guadalquivir existía un margen de control similar al que había en otros puntos de la costa de la Baja Andalucía. La gran diferencia estribaba en que en Sanlúcar eran los Medina Sidonia quienes decidían quién podía negociar y quién no y con qué grado de tolerancia, cuestión cuyos márgenes siempre resultaron conflictivos. 